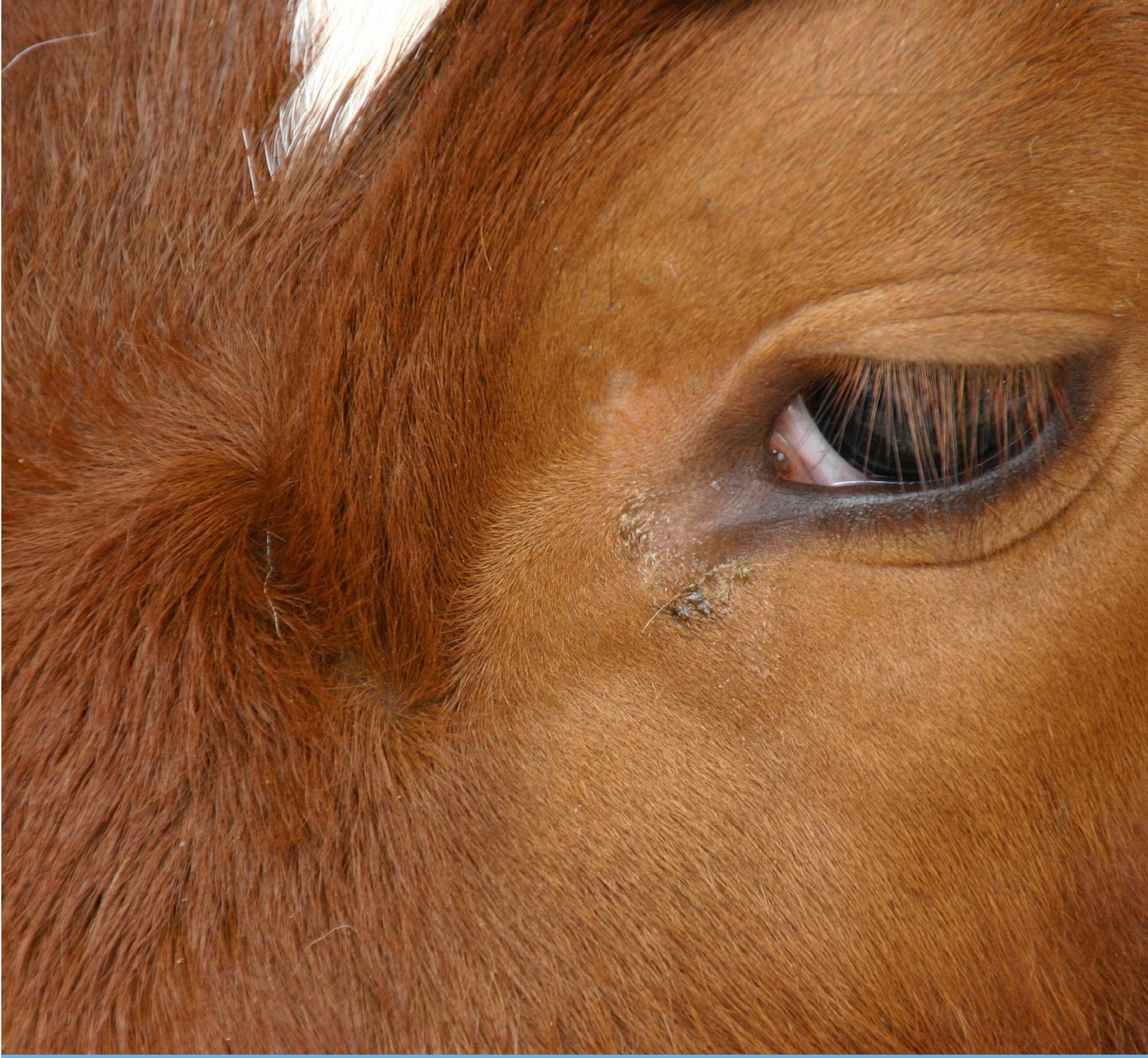

\title{
Evaluatie herziening UDD-regeling
}





\section{Evaluatie herziening UDD-regeling}

Martien Bokma, Karin Kreuger en Marion Kluivers

Wageningen Livestock Research

Dit onderzoek is uitgevoerd door Wageningen Livestock Research, in opdracht van en gefinancierd door het Ministerie van Landbouw, Natuur en Voedselkwaliteit, in het kader van het Beleidsondersteunend onderzoek thema 'Antibioticaproblematiek' (projectnummer BO-43-013.03-012)

Wageningen Livestock Research

Wageningen, mei 2020

Rapport 1254 
Martien Bokma, Karin Kreuger en Marion Kluivers, 2020. Evaluatie herziening UDD-regeling. Wageningen Livestock Research, Rapport 1254.

Samenvatting NL Op verzoek van het ministerie van Landbouw, Natuur en Voedselkwaliteit heeft Wageningen Livestock Research een evaluatie uitgevoerd onder sectordierenartsen (vleeskalver-, varkens- en melkveehouderij) en toezichthouders (NVWA). In de evaluatie is nagegaan of de herziening van de UDD-regeling d.d.1-1 2017 heeft geleid tot vergroting van de praktische werkbaarheid ervan. De evaluatie was gericht op de herzieningen inzake bedrijfsspecifieke aandoeningen en het op voorraad mogen hebben en inzetten van tweede keuze middelen (antibiotica) voor individuele behandelingen, alsmede op de vrijstellingen voor bedrijven met een structureel laag antibioticumgebruik. Het resultaat geeft inzicht in de veranderingen in praktische werkbaarheid en mogelijkheden voor verdere versterking ervan.

Summary UK At the request of the Ministry of Agriculture, Nature and Food Quality, Wageningen Livestock Research has conducted an evaluation among sector veterinarians (veal calf, pig and dairy husbandry) and supervisors (NVWA). The evaluation examined whether the revision of the UDD scheme dated 1-1 January 2017 has increased its practical feasibility. The review focused on the revisions regarding farm-specific diseases and the availability and stockpiling of second-choice antibiotics for individual treatments, as well as exemptions for farms with structurally low antibiotic use. The result provides insight into the changes in practical workability and possibilities for further strengthening it.

Dit rapport is gratis te downloaden op https://doi.org/10.18174/522116 of op www.wur.nl/livestock-research (onder Wageningen Livestock Research publicaties).

\section{(C) 2020 Wageningen Livestock Research}

Postbus 338, 6700 AH Wageningen, T 03174839 53, E info.livestockresearch@wur.nl, www.wur.nl/livestock-research. Wageningen Livestock Research is onderdeel van Wageningen University \& Research.

Wageningen Livestock Research aanvaardt geen aansprakelijkheid voor eventuele schade voortvloeiend uit het gebruik van de resultaten van dit onderzoek of de toepassing van de adviezen.

Alle rechten voorbehouden. Niets uit deze uitgave mag worden vermenigvuldigd en/of openbaar gemaakt worden door middel van druk, fotokopie, microfilm of op welke wijze dan ook zonder voorafgaande toestemming van de uitgever of auteur.

Wageningen Livestock Research is NEN-EN-ISO 9001:2015 gecertificeerd.

Op al onze onderzoeksopdrachten zijn de Algemene Voorwaarden van de Animal Sciences Group van toepassing. Deze zijn gedeponeerd bij de Arrondissementsrechtbank Zwolle. 


\section{Inhoud}

Woord vooraf $\quad 5$

$\begin{array}{ll}\text { Samenvatting } & 7\end{array}$

1

$\begin{array}{ll}\text { Inleiding } & 9\end{array}$

1.1 Wijzigingen UDD-regeling per 1-1-2017 9

$\begin{array}{lll}1.2 & \text { Onderzoeksvraag } & 10\end{array}$

$\begin{array}{lll}1.3 & \text { Leeswijzer } & 10\end{array}$

2

Werkwijze

Weergave van de interviews $\quad 12$

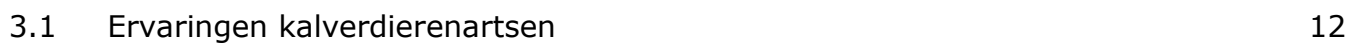

3.1.1 Bedrijfsspecifieke aandoeningen $\quad 12$

$\begin{array}{ll}3.1 .2 \text { Contactmoment } & 13\end{array}$

3.1.3 Vrijstelling voor bedrijven met een structureel laag antibioticumgebruik 14

3.1.4 Slotopmerkingen kalverdierenartsen 14

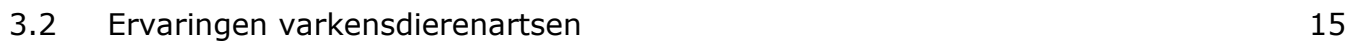

3.2.1 Bedrijfsspecifieke aandoeningen 15

3.2.2 Maximalisatie voorraad 16

3.2.3 Contactmoment 16

3.2.4 Vrijstelling voor bedrijven met een structureel laag antibioticumgebruik 17

$\begin{array}{ll}3.2 .5 \text { Slotopmerkingen varkensdierenartsen } & 18\end{array}$

3.3 Ervaringen dierenartsen voor melkvee 19

3.3.1 Bedrijfsspecifieke aandoeningen $\quad 19$

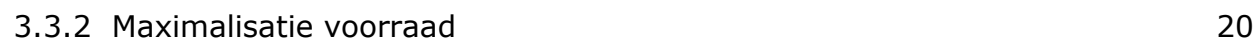

$\begin{array}{ll}\text { 3.3.3 Contactmoment } & 20\end{array}$

3.3.4 Vrijstelling voor bedrijven met een structureel laag antibioticumgebruik 21

3.3.5 Slotopmerkingen dierenartsen voor melkvee $\quad 21$

$\begin{array}{lll}3.4 & \text { Ervaringen NVWA-inspecteurs } & 22\end{array}$

3.4.1 Bedrijfsspecifieke aandoeningen $\quad 22$

$\begin{array}{ll}3.4 .2 \text { Maximalisatie voorraad } & 22\end{array}$

$\begin{array}{ll}3.4 .3 \text { Contactmoment } & 22\end{array}$

3.4.4 Vrijstelling voor bedrijven met een structureel laag antibioticumgebruik 23

$\begin{array}{ll}3.4 .5 & \text { Slotopmerkingen NVWA-inspecteurs } \\ & 23\end{array}$

4 Conclusies en aanbevelingen $\quad 24$

4.1 Conclusies en aanbevelingen m.b.t. de herziening 24

$\begin{array}{lll}4.2 & \text { Algemene aandachtspunten } & 27\end{array}$

$\begin{array}{ll}\text { Literatuur } & 28\end{array}$

$\begin{array}{lll}\text { Bijlage } 1 \text { Vragenlijst interviews } & 29\end{array}$ 


\section{Woord vooraf}

Op 1 januari 2017 zijn er wijzigingen op de UDD-regeling van kracht geworden. Daarbij is destijds door de staatssecretaris van Economische Zaken aangegeven dat zal worden geëvalueerd of deze wijzigingen de praktische werkbaarheid van de regeling hebben vergroot. Op verzoek van het ministerie van Landbouw, Natuur en Voedselkwaliteit hebben onderzoekers van Wageningen Livestock Research deze evaluatie uitgevoerd. Basis voor de evaluatie naar praktische werkbaarheid na de herziening van de UDD-regeling vormden (groeps-)interviews met sectordierenartsen en vertegenwoordigers van de toezichthouder (NVWA). De namen van de sectordierenartsen zijn aangedragen door de overkoepelende belangenvertegenwoordigers, te weten Stichting Brancheorganisatie Kalveren, Producenten Organisatie Varkens en Zuivel NL, Koninklijke Nederlandse Maatschappij voor Diergeneeskunde en Collectief Praktiserende Dierenartsen. Graag willen wij een ieder die heeft bijgedragen aan de uitvoering van de evaluatie, en in het bijzonder de personen die hebben meewerkt aan de interviews, hartelijk danken voor hun constructieve bijdrage aan het projectresultaat. Wij hopen dat de inzichten uit de evaluatie bijdragen aan verdere versterking van de praktische werkbaarheid en het realiseren van de doelen die overheid en bedrijfsleven hebben gesteld op het gebied van diergezondheid en zorgvuldig antibioticumgebruik.

Annemarie Rebel

Afdelingshoofd Diergezondheid en Dierenwelzijn

Wageningen Livestock Research 


\section{Samenvatting}

Op 1 januari 2017 is de herziene UDD-regeling van kracht geworden. Het ministerie van Landbouw, Natuur en Voedselkwaliteit (LNV) heeft Wageningen Livestock Research gevraagd om te evalueren of de herziening van de UDD-regeling heeft geleid tot een betere praktische werkbaarheid van deze regeling in de sectoren melkvee, varkens en vleeskalveren met het oog op de volgende onderdelen van de herziening:

- de maximaal drie bedrijfsspecifieke aandoeningen waarvoor tweede keuze middelen voor individuele behandeling op het veebedrijf op voorraad mogen zijn,

- de maximalisatie van deze voorraad tweede keuze middelen,

- het verplichte contactmoment met de dierenarts voorafgaand aan de inzet van deze middelen,

- $\quad$ en bepaalde vrijstellingen voor bedrijven met een structureel laag antibioticagebruik.

De evaluatie is uitgevoerd op basis van afzonderlijke groepsinterviews met een selectie van ervaringsdeskundige dierenartsen uit respectievelijk de kalver-, varkens- en melkveehouderij, alsmede met vertegenwoordigers van de toezichthouder (NVWA). De geïnterviewde dierenartsen zijn aangezocht in overleg met de veterinaire belangenbehartigers (KNMvD en CPD) en de sectororganisaties (POV, SBK en ZuiveINL).

\section{Belangrijkste conclusies en aanbevelingen}

$>$ Bedrijfsspecifieke aandoeningen Het werken met een top-3 van bedrijfsspecifieke aandoeningen in plaats van met sectorale knelpuntaandoeningen wordt in het algemeen als een verbetering ten opzichte van de oude UDD-regeling gezien. Dit geldt in het bijzonder voor de varkenssector, met als kanttekening dat de restrictie tot drie aandoeningen soms als te beperkt wordt ervaren bij aanwezigheid van meerdere diercategorieën op het bedrijf, met elk hun eigen kenmerkende aandoeningen. Dierenartsen voor de melkveesector werken bij voorkeur niet met bedrijfsspecifieke aandoeningen in bedrijfsbehandelplan (BBP) en bedrijfsgezondheidsplan (BGP). Het is voor de melkveesector minder relevant (hooguit neonatale kalverdiarree), en er is angst voor 'administratieve fouten'.

> Administreren van bedrijfsspecifieke aandoeningen in BBP Volgens de wet dient het BBP éénmaal per jaar te worden vastgesteld, of tussentijds te worden aangepast indien er een bedrijfsspecifieke aandoening bijkomt of verandert (tot max. 3). Dierenartsen uit de verschillende sectoren zijn voorstander van een variant waarbij ook de visitebrief lopende het jaar als addendum op BBP (en BGP) mag functioneren, in het geval dat er sprake is van een nieuwe aandoening met een structureel karakter (eveneens tot max. 3). Een variant met de visitebrieven als addendum heeft als voordeel een meer dynamische werkwijze, die veel beter aansluit bij de praktische werkbaarheid voor dierenarts en veehouder. Het BBP zelf hoeft in dat geval dan slechts éénmaal per jaar, tijdens de jaarlijkse evaluatie van BGP en BBP met de veehouder, te worden aangepast.

> Onderbouwing van bedrijfsspecifieke aandoeningen in BGP De bevraagde inspecteurs geven aan dat in de UDD-regeling niet is gespecificeerd aan welke eisen de omschrijving van bedrijfsspecifieke aandoeningen in het bedrijfsgezondheidsplan moet voldoen. Handhaving op een dergelijke open norm is lastig, in de regelgeving is niet concreet genoeg omschreven waarop men moet handhaven. Niet alleen voor de toezichthouder is dit een probleem, ook voor dierenartsen en hun veehouders levert dit veel onzekerheid op: het is niet duidelijk wanneer is voldaan aan de regels en hoe toezichthouders (publiek/privaat) hier mee om (moeten) gaan. In de regeling is evenmin gespecificeerd aan welke eisen de beschrijving van verbetermaatregelen in het BGP moeten voldoen. 


\section{> Maximalisatie voorraad tweede keuze middelen}

Voor vleeskalveren betrof dit geen herziening van de regeling (was al in de eerdere regeling opgenomen). Het op voorraad houden van tweede keuze middelen komt in de melkveepraktijk weinig voor. Varkensdierenartsen ervaren het als een grote uitdaging om te berekenen of men niet over de maximaal toegestane voorraad per afdeling heengaat. Een duidelijk nadeel van de herziening vindt men de term 'afdeling' waarvoor de maximalisatie van de voorraad geldt. Een voorraadmaximalisatie per leeftijdscategorie (zuigende biggen, gespeende biggen e.d.) in plaats van per afdeling zou de praktische werkbaarheid (sterk) vergroten.

> Contactmoment In de vleeskalversector, de varkenssector en de melkveesector wordt nauwelijks gebruik gemaakt van het contactmoment. Er wordt vrijwel altijd een bedrijfsbezoek afgelegd vóór inzet van een tweede keuze middel, of gebruik gemaakt van de reguliere bezoekfrequentie. Belangrijke reden hiervoor is om een beter beeld te hebben van wat er speelt, maar bovenal omdat de regelgeving rond het verplichte contactmoment door dierenartsen als te ingewikkeld en complex wordt ervaren (kalversector) of de praktische werkbaarheid als zeer negatief (varkenssector). De inspecteurs geven aan dat de herziening van de regeling ten aanzien van de bepalingen rondom het contactmoment niet heeft geleid tot een betere praktische werkbaarheid van de handhaving.

>Vrijstellingsregeling bij laag gebruik Binnen de vleeskalversector wordt weinig gebruik gemaakt van de vrijstellingsregeling voor laaggebruikers. Vrijstelling van de verplichte tweewekelijkse bedrijfsbezoeken tijdens de hoog-risico-periode is voor kalverbedrijven geen stimulans: juist in deze periode is frequente veterinaire zorg het meest relevant en standaard. Voor de varkenssector wordt de vrijstellingsregeling als zeer prettig ervaren, de praktische werkbaarheid is erdoor vergroot en het vormt een terechte waardering voor 'lage' bedrijven. De praktische werkbaarheid kan verder worden vergroot door via vaste ijkmomenten en/of via de IKB-systemen op ieder moment duidelijk te hebben welke bedrijven ervoor in aanmerking komen. Het is de dierenartsen niet duidelijk of de vrijstellingsregeling geldt per bedrijf of ook per leeftijdscategorie mag worden toegepast. Bijvoorbeeld, indien alleen de categorie vleesvarkens in het rode gebied zit, mag de vrijstelling dan wel worden toegepast op de categorieën met de zeugen en de biggen. $\mathrm{Er}$ is behoefte aan duidelijkheid hierover. Binnen de melkveesector wordt wisselend gebruik gemaakt van de vrijstellingsregeling: volgens sommige dierenartsen niet of nauwelijks, volgens andere volop. Voor meerdere dierenartsen zouden een DDDA per diercategorie, apart voor zowel melkkoeien als kalveren, en een daaraan gekoppelde vrijstellingsregeling meer zeggen dan per bedrijf, omdat de variatie in antibioticumgebruik tussen bedrijven juist bij de categorie kalveren vrij groot is. Binnen de vrijstellingsregeling mag worden volstaan met één bedrijfsbezoek per jaar aan het melkveebedrijf. Dit vinden de dierenartsen niet gewenst: de frequentie is dan onvoldoende om veterinair een vinger aan de pols te houden.

\section{Algemene conclusies met betrekking tot de herziening}

Zowel de vleeskalver- als varkensdierenartsen geven aan dat de herziening van de UDD-regeling in 2017 enige ontspanning c.q. versoepeling heeft gebracht. Volgens de kalverdierenartsen heeft het de praktische werkbaarheid niet veranderd, het sluit wel beter aan bij wat de sector al deed. De varkensdierenartsen geven aan dat er met de bedrijfsspecifieke aandoeningen ten opzichte van de knelpuntaandoeningen en met de vrijstellingsregeling zeker verbetering is opgetreden, en dat de uitvoering nu beter is te doen. Volgens de dierenartsen voor melkvee is de praktische werkbaarheid niet veranderd, alleen is op sommige punten de logistiek enigszins vereenvoudigd.

Dit laat onverlet dat er voor alle drie de sectoren nog een aantal uitermate belangrijke aandachtspunten qua praktische werkbaarheid resteren, en dat betreft met name de onzekerheid rondom de open normen. Dat wil zeggen, de wijze waarop bedrijfsspecifieke aandoeningen moeten worden opgenomen in het BBP en beschreven in het BGP (inclusief verbeterplan), en de min of meer onvoorspelbare wijze waarop toezichthouders (publiek/privaat) hiermee omgaan. Dit wordt ook door de bevraagde toezichthouders als uitermate lastig controleerbaar ervaren. Omwille van vergroting van de praktische werkbaarheid wordt tevens bepleit om de visitebrieven lopende het jaar als formeel addendum op BBP en BGP te accepteren. 


\section{$1 \quad$ Inleiding}

Op 1 januari 2017 is de gewijzigde UDD-regeling van kracht geworden. De wijzigingen kwamen voort uit een evaluatie (Kluivers et al., 2015) en zijn toegelicht in de Kamerbrief van 2 december 2016 (DGAN-DAD/29683-221). Daarin is tevens aangegeven dat de wijzigingen zullen worden geëvalueerd op praktische werkbaarheid. Het ministerie van Landbouw, Natuur en Voedselkwaliteit (LNV) heeft Wageningen Livestock Research gevraagd om deze evaluatie uit te voeren. In deze rapportage zijn de resultaten van de evaluatie weergegeven.

\section{$1.1 \quad$ Wijzigingen UDD-regeling per 1-1-2017}

In de herziene UDD-regeling per 1-1-2017 is een aantal vrijstellingen opgenomen voor bedrijven met een structureel laag antibioticagebruik en is het beleid voor het inzetten van tweede keuze middelen op een aantal punten gewijzigd. De wijzigingen op de UDD-regeling per 1-1-2017 zijn hierna samengevat.

\section{Bedrijfsspecifieke aandoeningen:}

In de herziene UDD-regeling wordt gewerkt met bedrijfsspecifieke aandoeningen in plaats van sectorspecifieke knelpuntaandoeningen. Voor maximaal 3 aandoeningen die op het bedrijf vaak voor problemen zorgen en waar acuut handelen noodzakelijk is, mogen tweede keuze middelen op voorraad zijn. Deze aandoeningen moeten vermeld zijn in het bedrijfsbehandelplan (BBP). In het bedrijfsgezondheidsplan (BGP) moet onderbouwd zijn waarom deze tweede keuze middelen voor de betreffende aandoening op het bedrijf aanwezig moeten zijn, en welke aanvullende maatregelen genomen worden om het optreden van de aandoening(en) te bestrijden en herhaling te voorkomen.

Maximalisatie voorraad:

In de regeling was al maximalisatie van de voorraad van eerste keuze middelen opgenomen (voor $15 \%$ van de aanwezige en voor de aandoening vatbare dieren). Voor alleen vleeskalveren was al maximalisatie van de voorraad tweede keuze middelen opgenomen (5\%). In de gewijzigde UDDregeling is nu ook voor melkveerunderen en varkens een maximalisatie van de voorraad tweede keuze middelen opgenomen: voor $10 \%$ van de op het bedrijf aanwezige en voor de aandoening vatbare melkveerunderen en voor $10 \%$ van in een afdeling aanwezige en voor de aandoening vatbare varkens.

\section{Contactmoment:}

Eerst gold dat de dierenarts in een periode van 14 dagen voorafgaand aan inzet van tweede keuze middelen bij individuele dieren het bedrijf moest hebben bezocht en geconstateerd dat de inzet nodig is. Per 1-1-2017 geldt dat de veehouder vóór inzet van tweede keuze middelen voor behandeling van individuele dieren eerst (of indien onbereikbaar binnen 24 uur) contact moet hebben gehad met zijn dierenarts. Dierenarts gaat akkoord of besluit het bedrijf te bezoeken, legt vast dat contactmoment heeft plaatsgevonden en zendt bij akkoord een instructie naar de veehouder (veehouder moet deze 5 jaar bewaren). Andere optie: dierenarts en veehouder besluiten gezamenlijk liever te blijven werken met het tweewekelijks bedrijfsbezoek en leggen dit vast in het BGP. NB Het tweewekelijks bedrijfsbezoek blijft sowieso verplicht voor behandeling met tweede keuze middelen tijdens een hoogrisico-periode (biggen tot een leeftijd van 8 weken; vleeskalveren de eerste 6 weken na opzet t/m leeftijd van maximaal 10 weken).

\section{Vrijstelling voor bedrijven met structureel laag antibioticumgebruik}

Per 1-1-2017 kan per veehouderijsector een 'gids van goede praktijken (GGP)' worden opgesteld, op basis waarvan het antibioticumgebruik van een veehouder kan worden erkend als 'structureel laag' en de veehouder in aanmerking komt voor een vrijstelling van: i) het evalueren van het antibioticumgebruik bij elk regulier bedrijfsbezoek, ii) het tweewekelijks bedrijfsbezoek door de dierenarts in de hoog-risico-periode (in dat geval gaat bij inzet van tweede keuze middelen het 
contactmoment gelden), iii) het jaarlijks aanscherpen van de reductiedoelstelling, iv) het 3maandelijks (of 6-maandelijks) regulier dierenartsbezoek voor melkveehouderijen, dit wordt dan omgezet in jaarlijks bezoek door de dierenarts.

GGP's per sector in 2019:

Vrijstelling verkrijgen Vrijstelling verliezen

Varkens: 3 opeenvolgende periodes van $1 / 2$ jaar in groen 2 of meer periodes in oranje/rood Melkvee: 6 opeenvolgende kwartalen in groen 4 of meer kwartalen oranje/rood Vleeskalveren: laatste 18 maanden in groen

2 halfjaar meetmomenten oranje/rood ( $1 / 2$ jaar meetmomenten)

\subsection{Onderzoeksvraag}

Overall doel van de evaluatie was om na te gaan of de herziening van de UDD-regeling de praktische werkbaarheid heeft vergroot. In de evaluatie stond de volgende onderzoeksvraag centraal:

Heeft de herziening van de UDD-regeling geleid tot een betere praktische werkbaarheid van deze regeling in de sectoren melkvee, varkens en vleeskalveren, met betrekking tot:

- het inzetten van tweede keuze middelen, specifiek op het gebied van:

- bedrijfsspecifieke aandoeningen;

- maximalisatie van de voorraad tweede keuze middelen;

- contactmomenten voorafgaand aan inzet van tweede keuze middelen;

- en vrijstellingen voor bedrijven met een structureel laag antibioticagebruik.

De evaluatie betrof uitsluitend de wijzigingen van de UDD-regeling, ingegaan op 1-1-2017, en niet de gehele UDD-regeling. Aangezien er voor de pluimveesector geen relevante wijzigingen in de UDDregeling zijn doorgevoerd, is door de opdrachtgever in overleg met de sector besloten deze sector niet mee te nemen in het onderzoek.

\subsection{Leeswijzer}

In hoofdstuk 2 staat de aanpak van de evaluatie beschreven. Hoofdstuk 3 geeft een weergave van de gehouden interviews en in hoofdstuk 4 zijn conclusies en aanbevelingen gegeven. 


\section{Werkwijze}

De data in het onderzoek zijn verzameld op basis van interviews met ervaringsdeskundigen uit de (veterinaire en toezichthoudende) praktijk, zijn kwalitatief van aard en uitsluitend geschikt voor een kwalitatieve analyse. De volgende werkwijze is gehanteerd:

1. Verzamelen en analyseren van gegevens over de praktische werkbaarheid via interviews met sectorspecifieke dierenartsen en NVWA-inspecteurs

a) De Koninklijke Nederlandse Maatschappij voor Dierenartsen (KNMvD), het Collectief Praktiserende Dierenartsen (CPD) en de sectorvertegenwoordigers (resp.

Producenten Organisatie Varkenshouderij (POV) namens de varkenssector, Stichting Brancheorganisatie Kalveren (SBK) namens de kalversector, en ZuivelNL namens de melkveesector) zijn vanuit het onderzoeksteam benaderd met het verzoek om elk twee namen aan te leveren van dierenartsen binnen de betreffende sectoren die aan een groepsinterview per sector mee zouden kunnen doen. Daarnaast is de NVWA benaderd met het verzoek eveneens namen van enkele inspecteurs met praktijkkennis over de UDD-regeling aan te leveren, die aan een groepsinterview (met alleen NVWA-vertegenwoordigers) mee zouden kunnen doen. Dit heeft er in geresulteerd dat met respectievelijk zes kalverdierenartsen, zes varkensdierenartsen, zes melkveedierenartsen en zeven NVWA-vertegenwoordigers een interview is gehouden.

b) $\mathrm{Er}$ is door het onderzoeksteam in afstemming met opdrachtgever en bovengenoemde organisaties een vragenlijst als leidraad bij de interviews opgesteld, en waar nodig specifiek gemaakt voor de betreffende doelgroep (bijlage 1).

c) De groepsinterviews per sector en met de NVWA zijn afgenomen door twee onderzoekers van Wageningen Livestock Research aan de hand van de vragenlijst. Van ieder groepsinterview is in concept een verslag opgesteld, dat ter verificatie is teruggelegd bij de personen die hebben deelgenomen aan het interview of waren aangedragen voor deelname, op de betreffende datum verhinderd waren en op het concept-verslag hebben gereflecteerd.

2. Optioneel: aanvullend telefonisch interviewen van een klein aantal veehouders Er was van te voren aangegeven dat, indien de interviews met dierenartsen en NVWA-inspecteurs hiertoe aanleiding zouden geven, een klein aantal veehouders telefonisch benaderd zou kunnen worden om een nadere uitdieping op specifieke aspecten van de praktische uitvoerbaarheid van de UDD-regeling te geven. Hiertoe was geen aanleiding, en van deze mogelijkheid is derhalve in de evaluatie geen gebruik gemaakt.

3. Rapportage Op basis van de bevindingen is een concept-rapportage opgesteld en voor commentaar voorgelegd aan de stuurgroep van het project bestaande uit opdrachtgever (ministerie van LNV) en de betreffende sectorvertegenwoordigers (varkens-, kalver- en melkveesector). Daarna is de rapportage door de onderzoekers definitief gemaakt. 


\section{$3 \quad$ Weergave van de interviews}

In dit hoofdstuk zijn de resultaten van de groepsinterviews met respectievelijk de kalverdierenartsen (3.1), de varkensdierenartsen (3.2), de dierenartsen voor melkvee (3.3) en de NVWAvertegenwoordigers (3.4) weergegeven. Het betreft hier een samenvatting van de genoemde ervaringen van de geïnterviewde sectordierenartsen en NVWA-vertegenwoordigers. In hoofdstuk 4 zijn hieruit door de onderzoekers conclusies getrokken met betrekking tot de centrale onderzoeksvraag.

\subsection{Ervaringen kalverdierenartsen}

Met zes kalverdierenartsen heeft een groepsinterview plaatsgevonden. Hierna zijn de opmerkingen van de kalverdierenartsen ten aanzien van de per 1-1-2017 ingegane wijzigingen van de UDD-regeling samengevat.

\subsubsection{Bedrijfsspecifieke aandoeningen}

\section{Praktische werkbaarheid}

In de herziene UDD-regeling wordt gewerkt met een top-3 van bedrijfsspecifieke aandoeningen in plaats van sectorspecifieke knelpuntaandoeningen. Voor vleeskalveren geldt dat de eerdere drie sectorspecifieke knelpuntaandoeningen, te weten artritis, enteritis en luchtweginfecties, nog steeds als top-3 op de meeste vleeskalverbedrijven voorkomen. Sinds de herziening kunnen de top-3 aandoeningen door de dierenartsen in het bedrijfsbehandelplan (BBP) worden opgenomen. De geïnterviewden geven aan dat in verschillende leeftijdsfasen (met name de periode 0-3 weken en 4 weken tot afvoer naar het slachthuis) een andere top-3 van bedrijfsspecifieke aandoeningen kan spelen. Het wordt daarbij als lastig ervaren om verschillende leeftijdscategorieën binnen één BBP te regelen en/of om meerdere malen het BBP te moeten aanpassen indien zich een nieuwe structurele aandoening aandient. De kalverdierenartsen zouden graag zien dat de visitebrief als formele aanvulling op het BBP én BGP zou mogen gelden. De visitebrief is in dat geval een verlengstuk van BBP (en bedrijfsgezondheidsplan (BGP): de motivatie voor een tweede keuze middel voor de betreffende bedrijfsspecifieke aandoening wordt dan ook in de visitebrief opgenomen). Het BBP en BGP zelf hoeven in dat geval slechts één keer per jaar, tijdens de jaarlijkse evaluatie van BBP en BGP, te worden aangepast.

Qua terminologie worden de bedrijfsspecifieke aandoeningen doorgaans op orgaansysteemniveau in het BBP vastgelegd. Dit werkt volgens de dierenartsen goed, omdat de ervaring leert dat veehouders ook vooral op deze wijze werken; zij spreken niet van pleuritis of van een Mycoplasma spp. infectie, maar van luchtwegaandoeningen.

Voor- en nadelen ten opzichte van de eerdere knelpuntaandoeningen De kalverdierenartsen ervaren geen specifieke voor- of nadelen van gebruik van drie bedrijfsspecifieke aandoeningen ten opzichte van de eerdere sectorspecifieke knelpuntaandoeningen.

Onderbouwing en beschrijving aanvullende maatregelen in BGP

De motivatie voor het voorhanden moeten hebben van tweede keuze middelen blijft heel algemeen in het BGP. Qua verbetermaatregelen is er vaak niets nieuws toe te voegen: iedere ronde is weer anders, o.a. vanwege wisselende kwaliteit van de kalveren. Het blijft om die reden bij een vrij algemeen actieplan. De beschreven maatregelen zijn vaak vrij algemeen, zoals klimaat optimaliseren, melk bereiden volgens schema en elektrolyten geven bij diarree. In de praktijk blijkt het lastig om op basis van een afgeronde ronde plannen te maken voor de komende ronde, omdat elke ronde totaal anders kan zijn. Het feit dat de kalveren elke ronde van andere melkveebedrijven/landen afkomstig zijn, speelt een zeer bepalende rol. Soms volstaat men ook met te verwijzen naar het algemene actieplan. Tijdens de lopende ronde vinden de dierenartsen het wel nuttig om de individueel gebruikte 
tweede keuze middelen op koppelniveau te evalueren. Bij de eindevaluatie van een ronde ligt de nadruk meer op de grote lijnen zoals klimaat, huisvesting enz.

\subsubsection{Contactmoment}

Praktische werkbaarheid

De kalverdierenartsen geven aan dat er praktisch weinig veranderd is ten opzichte van de oude situatie. Zo brengen ze vrijwel altijd een visite aan een bedrijf waar een kalverhouder een tweede keuze middel in wil zetten; dat is met de herziene regeling niet anders dan voorheen. De dierenartsen kiezen voor een visite in plaats van het contactmoment, omdat ze daarmee een beter beeld hebben van wat er speelt, maar bovenal omdat de regelgeving omtrent het verplichte contactmoment als te ingewikkeld en complex wordt ervaren. Aangevuld wordt dat een visite ook een mogelijkheid biedt om, indien dat nodig lijkt, een rem op gebruik van antibioticum te kunnen zetten, Eén dierenarts geeft aan in enkele gevallen wel gebruik te maken van de mogelijkheid om een tweede keuze middel op voorraad te hebben als een veehouder daarom vraagt. In z'n algemeenheid gebeurt dit naar schatting van de geïnterviewden op slechts enkele bedrijven binnen de kalversector, vooral op bedrijven die verder weg liggen van de dierenartspraktijk.

\section{Vorm en administratie}

In het BGP vermelden de dierenartsen waarom een tweede keuze middel is ingezet. Deze verklaring varieert: om uitval te verminderen of om welzijn te verbeteren, bijvoorbeeld omdat het ingezette eerste keuze middel geen of onvoldoende effect had. Ook wordt in het BGP vermeld wat het effect van de therapie was en wat maatregelen zijn om in de toekomst het risico op de betreffende aandoening te verminderen.

De ervaring leert dat er praktisch altijd tijdig contact wordt gelegd door een kalverhouder (d.w.z. voordat een behandeling wordt ingezet). Het vastleggen van het contactmoment vormt meestal geen probleem voor de dierenartsen, hoewel het lastig kan zijn als een contactmoment bijvoorbeeld tijdens een andere visite plaatsvindt. Bezoekverslagen binnen 24 uur realiseren is soms lastig. Ook hangt het vastleggen mede af van de frequentie van administreren. Zo doet de ene dierenartspraktijk dat dagelijks en de andere dat met een lagere frequentie. De praktische werkbaarheid is niet als zodanig veranderd, wel wordt de wijziging rondom contactmoment nu als soepeler ervaren omdat de regelgeving beter aansluit bij wat de dierenartsen al deden.

\section{Instructie inzet middelen + geldigheid termijn}

De meeste dierenartsen geven aan 's ochtends telefonisch spreekuur te houden waarop de veehouders kunnen inbellen om advies of een visite. De rest van de dag zijn de dierenartsen dan op locatie per telefoon bereikbaar (bellen/WhatsApp-en). Tijdens het contactmoment wordt tevens de instructie gegeven. Daarbij wordt het klinisch beeld beschreven op basis waarvan men een (volgend) kalf mag behandelen. Enkele dierenartsen geven aan dat er altijd contact is met een dierenarts voordat er een tweede keuze middel wordt afgegeven, aangezien de praktijkmedewerkers (dierenartsassistentes/ paraveterinairen) bij hen nooit zonder raadplegen van een dierenarts een tweede keuze middel mogen afgeven.

De geldigheidsduur die een dierenarts aangeeft bij een afgegeven instructie varieert. Bij de ene dierenarts is dit maximaal twee weken, bij een ander bijvoorbeeld vier. Ze geven tevens aan dat dit middel- en aandoening afhankelijk is. Voorbeeld: borstvliesontsteking/pleuritis kan over een langere periode optreden. Het is veelal een kwestie van opvoeden van veehouders; de meeste kalverhouders weten dat van hen wordt verwacht dat er na twee weken opnieuw contact wordt gelegd, en doen dit dan ook.

\section{Tijdelijke vervanging 1-op-1 dierenarts}

$\mathrm{Er}$ is op praktijkniveau geborgde vervanging van een dierenarts geregeld. Dit ligt vast in de 1:1 overeenkomst dierenarts-kalverhouder. In de gevallen dat er tijdens de spoeddienst een dierenarts nodig is, mag ook een niet-geborgde dierenarts een tweede keuze middel inzetten.

\section{Koppelkuur en verplichte visite}

In de vleeskalversector vormt de frequentie van de bedrijfsbezoeken vrijwel nooit een probleem. Bij integraties wordt er niet per visite betaalt en door de 'vrije mesters' wordt de hoogte van de prijs voor 
een visite door de kalverhouders als minimaal beschouwd (10\% van de rekening), en vormt daardoor geen belemmering. Zodoende blijkt er in de praktijk weinig verschil in frequentie van bedrijfsbezoeken te zijn tussen beide houderijvarianten.

\subsubsection{Vrijstelling voor bedrijven met een structureel laag antibioticumgebruik}

Praktische werkbaarheid - verkrijgen/verliezen vrijstelling

Dierenartsen ontvangen van Infokalf een overzicht van de hoogte van de dierdagdoseringen in de afgelopen anderhalf jaar. Ze weten daardoor goed waar de bedrijven staan ten aanzien van antibioticumgebruik. Wel ervaren de dierenartsen in toenemende mate een 'politieagent'-gevoel, aangezien er meer gecontroleerd moet worden. Dit speelt meer sinds de herziening van de UDDregeling. In de praktijk wordt er nauwelijks gebruik gemaakt van de vrijstellingsregeling. Juist de bedrijven die (lang) groen zijn, stellen volgens een dierenarts prijs op de zaken die volgens de vrijstelling niet zouden hoeven. Voor hen is dit dus geen beloning.

Effect evalueren AB-gebruik elk regulier bedrijfsbezoek + jaarlijks aanscherpen reductiedoelstelling Het evalueren van antibioticumgebruik wordt zowel tijdens (bij de reguliere bedrijfsbezoeken) als na afloop van een ronde gedaan. Van de vrijstellingsregeling voor laaggebruikers wordt niet vaak gebruik gemaakt, dus ook niet van de vrijstelling van evaluatie van antibioticumgebruik tijdens reguliere visites en van jaarlijks aanscherpen van de reductiedoelstelling.

Bij bedrijven die over de tijd heen laag scoren ('groene gebied'), zal de reductiedoelstelling jaarlijks geformuleerd worden als 'handhaven huidige status'. De dierenartsen vinden het voor bedrijven die wat hoger in het antibioticumgebruik zitten sowieso lastig om de vrijstelling te realiseren (d.w.z. structureel laaggebruiker te worden). In het geval dat er twee rondes achter elkaar hoger zijn, moet de ronde erna bijna niets worden gebruikt om dat op te heffen; wat in de praktijk zelden haalbaar blijkt.

\section{Frequentie bedrijfsbezoeken}

De vrijstelling voor structurele laaggebruikers met betrekking tot de verplichte tweewekelijkse bedrijfsbezoeken in de hoog-risico-periode heeft geen toegevoegde waarde volgens de dierenartsen. Het tweewekelijks (of doorgaans vaker) bezoeken van de vleeskalverbedrijven is zowel bij hoog- als laaggebruikers in deze periode al standaard, omdat het zeer zinvol is (in deze periode is veterinaire zorg het meest relevant).

\subsubsection{Slotopmerkingen kalverdierenartsen}

\section{Met betrekking tot de herziening}

Algeheel heeft de herziening van de UDD-regeling in 2017 ontspanning gebracht, maar de praktische werkbaarheid en de werkwijze zijn niet veel veranderd. Specifiek noemen de kalverdierenartsen dat er niet merkbaar meer regelgeving is bijgekomen. De herziening past feitelijk goed bij wat de sector al deed. Wel ervaren de kalverdierenartsen het als te veel regelgeving rondom individuele behandeling met tweede keuze middelen (zie ook hierna bij algemene aandachtspunten). Het gevolg is wel dat het gebruik iets strakker is geworden. Zo is er volgens de dierenartsen meer discipline bij de kalverhouders gekomen: kalverhouders zijn zich meer bewust van de middelen die ze inzetten, wat tot minder individueel gebruik van tweede keuze middelen lijkt te leiden.

\section{Algemene aandachtspunten}

In algemene zin zijn de dierenartsen van mening dat er in de regeling onevenredig veel aandacht wordt besteed aan individuele toepassing van tweede keuze middelen, terwijl de omvang ervan ten opzichte van de totale DDDA zeer beperkt is. Individuele inzet van tweede keuze middelen is veel minder een probleem qua omvang dan koppelkuren met deze middelen. Daarbij zijn deze middelen beperkt nodig in de vleeskalverhouderij, voorkómen kan in de regel niet.

Hoewel de regelgeving wat betreft maximalisatie van de voorraad niet is gewijzigd voor de vleeskalversector, geven de dierenarts gezamenlijk als aandachtspunt aan dat het verdwijnen van de inleverplicht ertoe kan leiden dat resthoeveelheden antibiotica alsnog worden gebruikt zonder vooraf raadplegen van de dierenarts. Dit kan mogelijk bijdragen aan het ontwikkelen van resistente kiemen; 
daarnaast is de werkzaamheid van een middel mogelijk verminderd doordat in sommige gevallen de maximale gebruiksdatum verstreken is.

Tot slot ervaren de dierenartsen het als zeer bezwaarlijk dat voorschrijven van antibiotica gebeurt op basis van bijsluiters die volgens hen niet up-to-date zijn.

\subsection{Ervaringen varkensdierenartsen}

Met zes varkensdierenartsen heeft een groepsinterview plaatsgevonden. Hierna zijn de opmerkingen van de varkensdierenartsen ten aanzien van de per 1-1-2017 ingegane wijzigingen van de UDDregeling samengevat.

\subsubsection{Bedrijfsspecifieke aandoeningen}

Praktische werkbaarheid

De varkensdierenartsen geven eensgezind aan dat het werken met bedrijfsspecifieke aandoeningen prettiger is dan met de knelpuntaandoeningen zoals eerder. Hoofdreden is dat er nu op bedrijfsniveau gekeken kan worden wat er speelt. Er zijn namelijk enkele aandoeningen die in de praktijk regelmatig alleen met tweede keuze antibiotica aan te pakken zijn, zoals Streptococcus suis en Escherichia coli. Dit geldt bijvoorbeeld ook voor het Porcine Respiratory Disease Complex. Meestal worden de bedrijfsspecifieke aandoeningen vrij gedetailleerd omschreven in het bedrijfsbehandelplan (BBP). Wel leeft de vraag of drie bedrijfsspecifieke aandoeningen voldoende is in geval van gesloten bedrijven, waar veel verschillende diergroepen aanwezig zijn. Dragende zeugen, lacterende zeugen, zuigende biggen, gespeende biggen en vleesvarkens/opfokzeugen kennen namelijk elk hun eigen kenmerkende aandoeningen. Het komt incidenteel voor dat er meer speelruimte nodig is dan de maximaal drie bedrijfsspecifieke aandoeningen, hoewel antibiotica meestal met name nodig zijn bij de zuigende en gespeende biggen. Ook komt ter sprake dat er per aandoening wordt beschreven, waarbij Streptococcus suis dan zowel bij de zuigende biggen als bij de gespeende biggen kan voorkomen. De dierenartsen geven aan dat niet duidelijk is of dit als één of twee aandoeningen dient te worden genoteerd. Al met al kunnen de dierenartsen goed uit de voeten met de herziene regeling omtrent de aandoeningen. Ze ervaren het met name als een papieren garantie dat er tweede keuze middelen op een bedrijf aanwezig mogen zijn.

Voor- en nadelen ten opzichte van de eerdere knelpuntaandoeningen Het wordt als voordeel ervaren dat er gewerkt mag worden met bedrijfsspecifieke aandoeningen in plaats van sectorale knelpuntaandoeningen.

Onderbouwing en beschrijving aanvullende maatregelen in BGP

Het is niet duidelijk wanneer de onderbouwing voor gebruik van een tweede keuze middel voldoende adequaat omschreven is in het BGP. Met name het (laten) uitvoeren van een (bacteriologisch onderzoek met) antibiogram is volgens de dierenartsen van belang voor de onderbouwing van een therapie met tweede keuze middelen. Het is niet duidelijk hoe vaak een monstername of een eventuele sectie herhaald moet worden voor een onderbouwing. Bovendien kan de gevoeligheid van middelen in vitro en in vivo verschillen, en kunnen antibiogrammen tussen verschillende dieren in het koppel eveneens verschillend zijn. De vraag is derhalve wanneer een onderbouwing afdoende is.

Daarbij is de ervaring van enkele varkensdierenartsen dat met name een gebrek aan volledige onderbouwing aanleiding voor een tuchtzaak kan zijn. Er is behoefte aan duidelijkheid ten aanzien van controles op onderbouwing van tweede keuze middelen in BBP en BGP; het wisselt per inspecteur wat deze verwacht. Deze willekeur van de toezichthouder is zeer lastig; voor beiden, zowel toezichthouder als dierenarts, is het handhavingskader niet geheel duidelijk.

Wat betreft de beschrijving van aanvullende maatregelen in het BGP benadrukken de dierenartsen dat het feit dat sommige aandoeningen nog niet zijn 'opgelost', aangeeft dat men niet altijd alles in de hand heeft. Er wordt een verbeterplan geschreven, maar een oplossing kan lastig zijn bij hardnekkige problemen. Daarbij speelt mee dat er op de meeste bedrijven wekelijks biggen worden geboren; dit continue proces zorgt ervoor dat de infectiedruk best hoog kan zijn. Daarbij is het BBP en BGP een 
statisch iets (evaluatie 1x per jaar), terwijl dierenarts en veehouder jaarrond bezig zijn om problemen op te lossen (en te voorkomen). De herziene UDD-regeling ondervangt dit niet. Ten tijde van deze evaluatie varieert het per dierenarts of het BGP lopende het jaar direct wordt gewijzigd indien hier aanleiding toe is, of op het jaarlijkse vaste evaluatiemoment. De varkensdierenartsen zouden graag zien dat de visitebrief als formele aanvulling op het BBP én BGP zou mogen gelden. De visitebrief is in dat geval een verlengstuk van BBP en BGP: de motivatie voor een tweede keuze middel voor de betreffende bedrijfsspecifieke aandoening wordt dan ook in de visitebrief opgenomen. Het BBP en BGP zelf hoeven in dat geval slechts één keer per jaar, tijdens de jaarlijkse evaluatie van BBP en BGP, te worden aangepast.

\section{Tips/opmerkingen}

Gezamenlijk geven de dierenartsen aan dat op de meerderheid van de bedrijven nauwelijks antibiotica worden gebruikt, daar gaat veel goed. Het gaat om de meer uitdagende en ingewikkelde bedrijven waar de regelgeving helder en duidelijk moet zijn. Ze ervaren de (herziene) UDD-regeling als papieren garantie dat middelen, hier tweede keuze middelen voor individueel gebruik, op een bedrijf aanwezig mogen zijn. Een belangrijke opmerking betreft de status van de visitebrief: kan deze geformaliseerd worden als aanvulling op BBP en BGP bij nieuwe structurele problemen gaandeweg het jaar, of moeten BBP en BGP telkens worden aangepast.

\subsubsection{Maximalisatie voorraad}

\section{Praktische werkbaarheid}

Het bijhouden van de voorraad op een bedrijf is erg lastig volgens de dierenartsen. Het is bijvoorbeeld een grote uitdaging om te berekenen welke biggen behandeld moeten worden, waarbij er ook nauwelijks zicht is op hoeveelheden restvoorraad. Zo ligt de verantwoordelijkheid wel bij de varkenshouder, maar moet de dierenarts het officieel aftekenen. Een verbeterpunt is om de verantwoordelijkheid meer bij de veehouder te leggen, zonder dat de dierenarts daar letterlijk gezien de controleur van is. Wat restvoorraad betreft: medicijnen worden, ondanks dat het wel is toegestaan, volgens de bevraagde varkensdierenartsen nooit retour genomen vanwege risico op ziektetransmissie. Dientengevolge wordt een restvoorraad ook niet verrekend bij vaststelling van de DDDA van een bedrijf.

\section{Voor- en nadelen t.o.v. oude regeling}

Een nadeel van de herziene regeling is de term 'afdeling' (voor max. 10\% van de in een afdeling aanwezige varkens mag tweede keuze middel voorhanden zijn). De toevoeging van de eenheid 'afdeling' maakt de praktische uitvoering lastig, omdat de geboorte van biggen op een zeugenbedrijf een continu proces is. Zo veranderen vaak wekelijks de afdelingsnummers, wat het lastig maakt om dier- en hokidentificatie te geven bij de instructie rondom individuele inzet van tweede keuze middelen. Liever zouden de dierenartsen per leeftijdscategorie voorschrijven, bijvoorbeeld 'biggen rond de geboorte (zuigende biggen)' of 'gespeende biggen'.

\section{Tips/opmerkingen}

Hoewel het ook al in de oude regeling gold, is het verschil tussen individuele versus koppelbehandeling niet altijd duidelijk. Het kan een discussie zijn of bijvoorbeeld colistine in een bakje voer in een hok van de kraamstal een koppelbehandeling is of niet. Wel is duidelijk dat middelen in injectievorm geregistreerd zijn voor individueel gebruik. Er is behoefte aan een definitie voor koppel; zodat medicatie door het water of over het voer ook op maat verstrekt kan worden aan enkele dieren tot een kleine groep. Met name de afbakening van het aantal dieren is daarin noodzakelijk.

\subsubsection{Contactmoment}

\section{Praktische werkbaarheid}

De praktische werkbaarheid van het contactmoment wordt door de varkensdierenartsen als zeer negatief ervaren. Er zou te veel contact moeten worden gemaakt vanuit een veehouder en de eigen dierenarts, feitelijk gezien zou elke injectie ampicilline besproken moeten worden. Dit is in de praktijk totaal niet haalbaar en er wordt dan ook nauwelijks gebruik gemaakt van het contactmoment. Waar nodig worden bedrijven tweewekelijks bezocht, bijvoorbeeld met een verkort bezoek tussendoor aan 
de betreffende diercategorie. Verder wordt er achteraf praktisch altijd geëvalueerd of een middel voldoende effect had. Bij bedrijven met een hoger antibioticumgebruik wordt er in de meeste gevallen gebruik gemaakt van een tweewekelijks bedrijfsbezoek, dit bevalt dan goed. Wat ook als verbetering wordt gezien, is dat er minder visites nodig zijn, omdat tweede keuze middelen op voorraad mogen zijn. De praktische werkbaarheid van het (al in de oude regeling verplichte) tweewekelijks bedrijfsbezoek tijdens de hoog-risico-periode (biggen tot een leeftijd van 8 weken) vindt men goed. De dierenartsen ervaren daarmee meer grip te hebben op de situatie. Dit verandert niets aan het voorschrijven van medicatie, maar de dierenarts zit er dichter op, wat positief uitwerkt.

\section{Vorm en administratie}

Hoe het contactmoment wordt ingevuld, varieert per dierenarts. Sommige dierenartsen gebruiken het bestellen van antibiotica als contactmoment. Daarbij geven ze dan tevens de gebruiksinstructie, meestal als visitebrief. Dit geldt dan bij bedrijven die de vrijstelling voor laaggebruikers hebben en structureel in het groene gebied zitten (en dus niet verplicht tweewekelijks bezocht hoeven te worden in de hoog-risico-periode). Een andere dierenarts beschrijft de gehanteerde werkwijze als volgt: zodra een tweede keuze middel met enige regelmaat wordt ingezet, wordt het bedrijf als 'rood' benoemd en volgt er tweewekelijks visite. Voor restproducten geldt dat de veehouder dit naar keuze kan inzetten, zonder contactmoment. Hier is dan geen controle op.

\section{Instructie inzet middelen + geldigheid termijn}

Volgens de dierenartsen is hoofddoel van de UDD-regeling dat de veehouder meer autonomie heeft. Om dat te bereiken dient in het BGP en BBP al vastgelegd te zijn wat werkwijzen moeten zijn. Ook de instructie van middelen wordt hier al in vastgelegd, hoewel indien nodig instructie op maat wordt verstrekt. Aan de maximale geldigheidsduur van bijvoorbeeld een klinische inspectie is geen limiet verbonden. Er is geen einddatum aan een gemaakte afspraak. In de praktijk wordt de frequentie van bedrijfsbezoeken hiervoor gehanteerd; bij een vierwekelijks visite is dat dan vier weken. Aangezien de dierenarts vanwege de wettelijke verplichting elke vier weken op een bedrijf moet komen, wordt het meestal zo opgelost.

Tijdelijke vervanging 1-op-1 dierenarts

Niet specifiek besproken.

Koppelkuur en verplichte visite

Voorafgaand aan inzetten van een koppelkuur wordt er altijd een visite afgelegd, ook als dit slechts enkele dagen later alweer het geval is. Ook bij het bijbestellen van medicatie wordt hierop gelet door de dierenarts.

\subsubsection{Vrijstelling voor bedrijven met een structureel laag antibioticumgebruik}

\section{Praktische werkbaarheid - verkrijgen/verliezen vrijstelling}

Dierenartsen ervaren de mogelijkheid tot deze vrijstelling voor structureel lage bedrijven als prettig, de praktische werkbaarheid is vergroot hierdoor. Wel is het lastig om vast te stellen welke bedrijven hiervoor in aanmerking komen. Dat komt mede door het feit dat er geen ijkmomenten zijn waarop wordt bepaald of een bedrijf laag genoeg bevonden wordt of niet. Door het invoeren van vaste ijkmomenten is de verwachting dat de praktische werkbaarheid verder wordt vergroot. Idealiter wordt dit ingericht zoals ook voor Salmonella geldt, namelijk voortschrijdend.

Een ander vraagstuk is hoe omgegaan dient te worden met gesloten bedrijven, waarbij bijvoorbeeld de vleesvarkens in het rode gebied scoren, maar de zeugen/zuigende biggen en gespeende biggen in het groen. Het is dan onduidelijk hoe hier in het kader van de vrijstellingsregeling mee om mag worden gegaan. De varkensdierenartsen vinden het een belangrijke verbetering als de regelgeving op diergroep-niveau zou worden afgestemd. Ook zouden de dierenartsen graag bijvoorbeeld de beide IKB-systemen laten indelen of een bedrijf groen of rood is en voor de vrijstelling in aanmerking komt op basis van de voorgaande perioden. Tot slot geven de dierenartsen aan dat ze zelf filteren of een bedrijf in aanmerking komt voor de vrijstelling; dit wordt meestal niet naar de veehouder als zodanig gecommuniceerd. Daarbij zullen bij nieuwe benchmarkwaarden meer bedrijven in het rood komen. Dierenartsen hebben niet de indruk dat het mogelijk verkrijgen van de vrijstelling een grote drive vormt voor veehouders die structureel in het rode gebied zitten. 
Effect evalueren AB-gebruik elk regulier bedrijfsbezoek + jaarlijks aanscherpen reductiedoelstelling Het evalueren van ingezette therapie gebeurt altijd, maar er wordt niet tot op de komma nauwkeurig berekend en geverifieerd hoeveel er gebruikt is van een bepaald middel. De dierenartsen evalueren het antibioticumgebruik per definitie als het hoog is. Daarbij kan zich de situatie voordoen dat de huisvesting van de dieren verouderd is; op een 'rood' bedrijf met een oude stal kan het continu evalueren van dezelfde punten eerder demotiverend dan motiverend werken. Het vrijstellen van het jaarlijks aanscherpen van de reductiedoelstelling voor structureel lage bedrijven wordt als zeer fijn ervaren, dat is een gunstig effect van de herziene UDD-regeling. Idealiter zou dit ook omgekeerd moeten gelden; dus als dierenarts het advies kunnen geven om meer antibioticum te gebruiken. Dat kan met name relevant zijn in situaties waar volgens een antibioticumvrij concept wordt geproduceerd en gelijktijdig sprake is van structurele gezondheidsproblemen.

\section{Frequentie bedrijfsbezoeken}

Het vervallen van de verplichte tweewekelijkse bedrijfsbezoeken (tijdens de hoog-risico-periode) heeft geen meerwaarde op met name wat grotere bedrijven, waar de dierenarts vaak standaard tweewekelijks het bedrijf bezoekt voor een visite. In andere gevallen kan het wel gunstig zijn, maar moet het contact op een andere manier ingevuld worden om voldoende vinger aan de pols te kunnen houden.

\subsubsection{Slotopmerkingen varkensdierenartsen}

\section{Met betrekking tot de herziening}

De praktische werkbaarheid van de herziene UDD-regeling wordt in het geheel als soepeler ervaren. Er is zeker verbetering opgetreden, met name de uitvoering is nu beter te doen. Punt blijft echter wel dat de verantwoording en de onderbouwing (verslaglegging) met extreem grote nauwkeurigheid plaatsvinden, uit angst dat het bij controles tot problemen leidt. Het vastleggen van afspraken, bevindingen en uitslagen vindt men op zich goed, dat doet men ook naar eer en geweten, maar het is onduidelijk wat volledig goed is; wat bij controles dan soms tot problemen leidt. De dierenartsen ervaren de herziene regeling als nadelig als het gaat om overzichtelijkheid van de regelgeving; zo is het ook voor jonge dierenartsen een grote uitdaging alle finesses van de UDD-regeling, ook na de herziening, in de vingers te krijgen.

\section{Algemene aandachtspunten}

Een grote behoefte vanuit de varkensdierenartsen is dat het huidige formularium wordt toegespitst op de farmacokinetiek, wat er in de praktijk gebeurt (vooral wat het effect is van een bepaald middel) en wat (internationale) politieke ontwikkelingen zijn. Zo is Nederland een van de weinige landen waar ampicilline en amoxicilline als tweede keuze middelen gelden, in andere landen zijn dit eerste keuze middelen. Voor de practicus zijn dit belangrijke middelen. Idealiter wordt het formularium afgestemd op de Europese ontwikkelingen. Hoewel dit losstaat van de hier geëvalueerde herziening, kan het meenemen van vragen als deze leiden tot groter draagvlak bij zowel dierenarts als veehouder.

Een tweede punt is dat het handhavingskader van waaruit de NVWA werkt niet bekend is bij de dierenartsen. Men wil graag proactief werken, wat niet mogelijk is als dit kader niet gedeeld wordt. Met name het gevoel, maar zeker ook de ervaring dat klachtenprocedures steeds vaker op de letterlijke formulering van bijvoorbeeld de onderbouwing gebaseerd zijn, zorgt voor een onveilig gevoel. De regelgeving voelt soms als een spagaat; ze willen het goed doen voor een veehouder, maar niet in de laatste plaats ook voor de wet.

Tot slot wordt het als een tegenstrijdigheid ervaren dat de UDD-regeling een vrijstelling is voor veehouders om antibioticum in te mogen zetten, maar dat men het vervolgens noodzakelijk acht er zeer uitgebreide en bovenal complexe regelgeving aan te koppelen. Tegelijkertijd dient de dierenarts te verifiëren dat de veehouder professioneel heeft gehandeld. Scholing van veehouders en personeel vindt men een belangrijk punt. Een aanbeveling is om competenties van varkenshouders/personeel aantoonbaar te maken (scholing te certificeren); aantoonbaar maken dat de veehouder professioneel genoeg is om bewust en weloverwogen antibioticum in te zetten. De verantwoordelijkheid voor het professioneel handelen rondom de voorgeschreven antibiotica op het bedrijf ligt dan bij de veehouder. Zo wordt voorkomen dat de dierenarts naast bedrijfsadviseur ook controleur is. 


\subsection{Ervaringen dierenartsen voor melkvee}

Met zes dierenartsen voor melkvee heeft een (groeps-)interview plaatsgevonden. Hierna zijn de opmerkingen van de dierenartsen voor melkvee ten aanzien van de per 1-1-2017 ingegane wijzigingen van de UDD-regeling samengevat.

\subsubsection{Bedrijfsspecifieke aandoeningen}

Praktische werkbaarheid

Voor de melkveesector was neonatale kalverdiarree de enige knelpuntaandoening in de oude UDDregeling. Hoewel er in de herziene regeling (maximaal) drie bedrijfsspecifieke aandoeningen vastgelegd kunnen worden, leert de ervaring dat nog steeds voornamelijk neonatale kalverdiarree eruit springt qua structurele aandoeningen op melkveebedrijven. In het kader van bedrijfsspecifieke aandoeningen worden er nauwelijks tweede keuze middelen ingezet. Eén dierenarts heeft de ervaring dat inzet van tweede keuze middelen ter behandeling van neonatale kalverdiarree een hoge uitzondering is: naar inschatting op jaarbasis maximaal $5 \%$ van de bedrijven en, zoals ook de andere dierenartsen aangeven, dan altijd als tijdelijke maatregel.

De meeste bevraagde dierenartsen geven aan dat ze het liefst zo min mogelijk gebruik maken van de (herziene) UDD-regeling met betrekking tot de bedrijfsspecifieke aandoeningen waarvoor tweede keuze middelen op voorraad mogen zijn. Ze nemen het bij voorkeur niet op in het BGP en BBP. Er is door de dierenartsen doorgaans wel (maar soms ook niet) gecommuniceerd naar de melkveehouders dat de herziene regeling ten aanzien van bedrijfsspecifieke aandoeningen bestaat, maar ook dat de administratieve lasten dan voor rekening van de veehouder komen.

Eén dierenarts geeft aan de herziene UDD-regelgeving ten aanzien van bedrijfsspecifieke aandoeningen in het BGP en BBP wel met enige regelmaat te gebruiken, zodat een voorraad tweede keuze middelen voor individuele behandelingen is toegestaan; deze dierenarts heeft ook ervaring met bedrijfsspecifieke aandoeningen en tweede keuze middelen op voorraad in de intensieve veehouderij. Wanneer een tweede keuze middel ingezet wordt, is de afspraak dat de veehouder de dieridentificatie van de behandelde dieren bijhoudt en dat er na twee weken een (telefonische) evaluatie plaatsvindt.

De dierenartsen geven aan dat ze in situaties waarin behoefte is aan directe inzet van tweede keuze middelen voor individuele behandeling (d.w.z. op voorraad hebben), bij voorkeur zouden werken met een addendum op het BBP. Daarin kan dan vermeld worden dat bijvoorbeeld Parofor $§$ (antibioticum tegen kalverdiarree) tijdelijk ingezet mag worden. Dit dient dan te gebeuren na een passende anamnese en diagnostiek.

De deelnemers aan het gesprek zijn echter eensgezind: over het algemeen wordt er op melkveebedrijven nauwelijks tot niet gebruik gemaakt van de regeling. Hoofdreden hiervoor is de grote voorzichtigheid en zelfs angst dat men iets verkeerd doet. De ervaring is dat controlerende instanties, de NVWA, maar ook VERIN enz. elk hun eigen beleid hebben, terwijl niet in alle gevallen duidelijk gecommuniceerd wordt waaraan voldaan moet worden. Veehouders vragen er doorgaans ook niet naar. Dierenartsen willen zich er niet aan 'branden', en houden ook liever zelf de vinger aan de pols ten aanzien van inzet van tweede keuze middelen.

Voor- en nadelen ten opzichte van de eerdere knelpuntaandoeningen

Er worden geen specifieke voor- of nadelen ten opzichte van knelpuntaandoeningen ervaren.

Onderbouwing en beschrijving aanvullende maatregelen in BGP

Alleen Parofor ${ }^{\circledR}$ wordt nog wel eens op voorraad gehouden voor kalverdiarree. Kalverdiarree wordt dan als specifieke aandoening opgenomen in het BGP, waarbij de focus op biosecurity, hygiëne, enz. wordt gelegd als aanvullende maatregelen. Soms is renovatie of nieuwbouw de enige oplossing om structurele gezondheidsproblemen op te lossen. Zo lang dat niet mogelijk is, bijvoorbeeld vanwege beperkte financiën, kan een bedrijfsspecifieke aandoening min of meer structureel op het BGP blijven staan. 


\section{Tips/opmerkingen}

Dierenartsen geven aan dat het lastig te volgen is voor praktijkmedewerkers (dierenartsassistentes/ paraveterinairen) of een bepaald middel meegegeven mag worden aan een veehouder. Eén dierenarts geeft aan dat zij de werkwijze hanteren dat middelen in hun apotheek gelabeld zijn met rood/groen; waarbij groen te allen tijde mee mag worden gegeven en rood alleen door een dierenarts. Sommigen werken met een extra regel bij de productomschrijving in het logboek en in het PraktijkManagementSysteem (PMS): zo is voor een ieder duidelijk of er sprake is van een eerste of tweede keuze middel.

\subsubsection{Maximalisatie voorraad}

Praktische werkbaarheid

Het op voorraad houden van tweede keuze middelen komt in de praktijk zoals aangegeven weinig voor, alleen voor Parofor ${ }^{\circledR}$ zo nu en dan. Enkele dierenartsen geven aan dat veehouders het lastig lijken te vinden om voorraad bij te houden; een stukje eigen verantwoordelijkheid ontbreekt daarin. De dierenarts heeft daardoor volgens hen in veel gevallen een meer controlerende dan een adviserende rol gekregen, wat in principe niet de bedoeling is. De praktische werkbaarheid van de herziening is dientengevolge niet verbeterd. Een andere dierenarts herkent dit beeld niet: op het logboek staat altijd duidelijk omschreven onder welke voorwaarden een tweede keuze middel is voorgeschreven en onder welke voorwaarden het middel al dan niet bij een ander dier gebruikt mag worden. Professionele voorlichting en advies hoort volgens deze dierenarts bij de rol van de dierenarts als apotheker.

De dierenartsen geven aan een toegestane voorraad tweede keuze middelen voor $10 \%$ van de op het bedrijf aanwezige melkkoeien hoog te vinden. Een voorraadmaximalisatie van $10 \%$ vindt men voor de op het bedrijf aanwezige en voor de aandoening (kalverdiarree) vatbare kalveren wel relevant.

Voor- en nadelen t.o.v. oude regeling

Er zijn geen specifieke voor- of nadelen van de herziene UDD-regeling ten opzichte van de oude regeling gegeven.

\section{Tips/opmerkingen}

Losstaand van de herziening geven dierenartsen aan dat het in sommige dierenartspraktijken gewoonte is dat veehouders ongebruikte antibiotica weer inleveren bij de praktijk. Daarbij wordt de hoeveelheid verrekend met de DDDA, wat positief uitwerkt voor de veehouders.

\subsubsection{Contactmoment}

Praktische werkbaarheid

De praktische werkbaarheid is niet veranderd met de herziene regeling.

Vorm en administratie

Het contactmoment verloopt niet veel anders dan vóór de herziening. In veel gevallen gaat het contact per telefoon en WhatsApp. Wel vragen dierenartsen zich af of de veehouders het contactmoment goed terug weten te vinden in het geval van een controle. Het contactmoment wordt ook in het PMS vastgelegd. Daarbij wordt aangegeven dat met het ene PMS-systeem lastiger specifieke informatie kan worden teruggevonden dan met het andere.

Instructie inzet middelen + geldigheid termijn

Instructies worden per visitebrief gegeven. Met het geven van geldigheidstermijnen gaan dierenartsen wisselend om: sommige doen dit wel, andere niet altijd.

Tijdelijke vervanging 1-op-1 dierenarts

Ook tijdelijke vervanging gebeurt doorgaans door geborgde rundveedierenartsen. 


\subsubsection{Vrijstelling voor bedrijven met een structureel laag antibioticumgebruik}

Praktische werkbaarheid - verkrijgen/verliezen vrijstelling

Er wordt wisselend gebruik gemaakt van de vrijstellingsmogelijkheden: volgens sommige dierenartsen niet of nauwelijks, volgens andere volop. Indien er sprake is van vrijstelling, wordt dit gemeld op het BGP. De signaleringswaarde van 6 DDDA vinden de dierenartsen best hoog. Door selectief droogzetten is het antibioticumgebruik verder naar beneden gegaan. Algemeen heeft men het gevoel dat het antibioticumgebruik bij melkkoeien zeker niet verder naar beneden moet.

Effect evalueren AB-gebruik elk regulier bedrijfsbezoek + jaarlijks aanscherpen reductiedoelstelling De variatie in de hoeveelheid gebruikte antibiotica bij de kalveren is tussen bedrijven vrij groot. Bij volwassen dieren zit daar tussen de bedrijven minder verschil in. Daarom zou een DDDA-kengetal per diercategorie met een daaraan gekoppelde vrijstelling meer zeggen dan een DDDA op bedrijfsniveau. In het BGP dient genoteerd te worden wat de DDDA gemiddeld is, evenals de DDDA in de groep 0 - 56 dagen en 56 dagen - 1 jaar. Als daar opvallende zaken zijn, geeft de dierenarts daar al dan niet een toelichting en/of advies bij.

\section{Frequentie bedrijfsbezoeken}

Op melkveebedrijven met een structureel laag gebruik mag volgens de UDD-vrijstellingsregeling worden volstaan met een jaarlijks bedrijfsbezoek door de dierenarts. Voor andere melkveebedrijven is het wettelijk verplicht dat de dierenarts minimaal vier keer per jaar op het bedrijf komt. Vrijstelling van de verplichte bedrijfsbezoeken per jaar naar één bedrijfsbezoek vinden de bevraagde dierenartsen niet gewenst: de dierenarts komt dan te weinig op het bedrijf om een vinger aan de pols te kunnen houden. De aan KoeKompas gekoppelde papieren (KoeData) en fysieke (KoeAlert) controles, waaruit zou moeten blijken dat de dieren gezond zijn, vindt men niet voldoende als vervanging.

\subsubsection{Slotopmerkingen dierenartsen voor melkvee}

Met betrekking tot de herziening

Sommige dierenartsen voor melkvee zien de UDD-regeling, ook na de herziening, nog steeds als een instrument wat het voor veehouders minder aantrekkelijk maakt om contact op te nemen met hun dierenarts. Dat ervaren deze dierenartsen als nadelig. Een andere dierenarts deelt deze ervaring niet en geeft aan juist meer vragen van veehouders te krijgen: veehouders willen het goede doen, bij twijfel nemen ze contact op met de dierenarts, ook over aandoeningen omschreven in het BBP. De praktische werkbaarheid in het geheel is niet veranderd, alleen is het op sommige punten logistiek enigszins vereenvoudigd.

\section{Algemene aandachtspunten}

Wat duidelijk naar voren kwam tijdens het gesprek is dat de gedetailleerdheid van de verslaglegging van zeer groot belang is. De ervaring leert dat hier veel mis kan gaan, ook door onduidelijkheid in het beleid van toezichthouders, met vergaande gevolgen zoals ingediende klachten voor de betreffende dierenarts. Kennis van de geldende regelingen is daarbij dus van groot belang. Daarbij blijft het de vraag wie waar door toezichthouders voor verantwoordelijk wordt gehouden in het samenspel tussen veehouder en dierenarts.

Verder gaat de UDD-regeling ervan uit dat er een BGP is. Er is onder een aantal dierenartsen verwarring ontstaan over de status van de KoeMonitor in relatie met het BGP. De onderbouwing zou ontbreken van het op voorraad mogen hebben van tweede keuze middelen. Daarbij vinden de dierenartsen het lastig dat bij melkvee relatief weinig bedrijfsbezoeken verplicht zijn (vier), in tegenstelling tot de intensieve veehoudersectoren, en dat er relatief gemakkelijk kan worden voldaan aan de vrijstellingsregeling. Het is voor de dierenarts bij een éénmalig bedrijfsbezoek per jaar lastiger om een vinger aan de pols te houden. 


\subsection{Ervaringen NVWA-inspecteurs}

Met zeven vertegenwoordigers van de NVWA heeft een (groeps-)interview plaatsgevonden. Hierna zijn de opmerkingen van de NVWA ten aanzien van de per 1-1-2017 ingegane wijzigingen van de UDDregeling samengevat.

\subsubsection{Bedrijfsspecifieke aandoeningen}

In de praktijk zijn de sectorale bedrijfsspecifieke aandoeningen volgens de inspecteurs veelal dezelfde als de eerder geldende sectorspecifieke knelpuntaandoeningen. Zij geven aan dat de praktische werkbaarheid van de handhaving niet is beïnvloed door deze verandering.

In het BGP moet onderbouwd zijn waarom voor de betreffende bedrijfsspecifieke aandoening tweede keuze middelen op het bedrijf aanwezig moeten zijn. In de regeling zelf is echter niet gespecificeerd aan welke eisen de omschrijving in het BGP precies moet voldoen. In de praktijk blijkt de omschrijving van de aandoeningen te variëren van 'waarschijnlijkheidsdiagnose Mycoplasma spp.' tot het abstracte 'respiratiestelsel'. De onderbouwing waarom voor de betreffende aandoening tweede keuze middelen op voorraad moeten zijn, is meestal wel goed in het BGP beschreven. Aanvullende maatregelen in het BGP om het optreden ervan te bestrijden en in de toekomst te voorkomen zijn vaak weinig vernieuwend: de werkwijzen op een bedrijf veranderen zelden ingrijpend. Voorbeeld: in de praktijk blijken vooral kleine wijzigingen doorgevoerd te worden, zoals gaan desinfecteren, biggen minder mengen bij opleg, enz. Met name in geval van nieuwbouw kan de werkwijze wel aanzienlijk veranderen. De inspecteurs benadrukken dat handhaving op open normen zoals ten aanzien van de bedrijfsspecifieke aandoeningen in het BGP lastig is, in de regelgeving is niet concreet genoeg beschreven waarop men moet handhaven. Dit was vóór de wijziging per 1-1-2017 ook al het geval met de sectorspecifieke aandoeningen. In dat opzicht ervaren de inspecteurs wat betreft de uitvoerbaarheid van inspecties geen specifieke voor- of nadelen bij het controleren op naleving van gebruik van bedrijfsspecifieke aandoeningen nu er geen knelpuntaandoeningen meer worden gebruikt. Tevens levert het niet meer werk op.

\subsubsection{Maximalisatie voorraad}

De inspecteurs geven aan dat controle op de naleving van de wijziging ten aanzien van een maximale aanwezige voorraad tweede keuze middelen op een bedrijf vrij eenvoudig is, doordat het om een getal gaat. Het is een kwestie van aanwezige dieren tellen en de toegestane voorraad ten opzichte van die aanwezige dieren berekenen. Wat dat betreft zijn er geen voor- of nadelen ten opzichte van de al eerder bestaande regeling: ook toegestane voorraden van bv. eerste keuze middelen worden op deze manier berekend. Dit geldt voor zowel melkvee als varkens (bij vleeskalveren waren er geen wijzigingen op dit specifieke onderdeel).

Het op peil houden van de (beperkte) maximale voorraad zien de inspecteurs niet als een probleem voor de bedrijven. Bij inzet van tweede keuze middelen bij individuele dieren kennen varkensvermeerderingsbedrijven een hoog-risico-periode bij de gespeende biggen (tot 8 weken leeftijd), waardoor de dierenarts daar per definitie tweewekelijks op het bedrijf komt. Ook voor vleeskalverbedrijven geldt een hoog-risico-periode waarbinnen de dierenarts iedere twee weken op het bedrijf is (tot 6 weken na opzet). Tevens geldt er standaard een wettelijk verplichte bezoekfrequentie door de dierenarts, te weten 4-wekelijks voor varkensbedrijven, 3-maandelijks voor vleeskalverbedrijven en 3- of 6-maandelijks voor melkveebedrijven. De inspecteurs hebben geen indicaties vanuit de praktijk dat de maximalisatie van de toegestane voorraad tweede keuze middelen tot praktische problemen leidt.

\subsubsection{Contactmoment}

Met de wijziging per 1-1-2017 geldt dat de veehouder vóór inzet van tweede keuze middelen ter behandeling van individuele dieren eerst (of indien onbereikbaar binnen 24 uur) contact moet hebben gehad met zijn dierenarts. De dierenarts moet het contactmoment en de instructie aan de veehouder vastleggen. De inspecteurs geven aan dat naleving hiervan feitelijk niet te controleren is ('papieren tijgers'). Er zit rekbaarheid in het contactmoment, de verantwoording kan ook na de inzet van de middelen administratief worden geregeld. Wel blijken de instructies die gelden voor de inzet van 
antibiotica in de praktijk vrijwel altijd voldoende te zijn. Echter, er bestaat geen maximale geldigheidsduur aan een akkoord van een dierenarts, dat wil zeggen hoe lang een veehouder het betreffende middel bij individuele dieren mag inzetten. Hierop kunnen inspecteurs dientengevolge ook niet controleren. Gebruik van WhatsApp als bewijs voor contactmoment en instructie maakt het extra lastig: hoeveel stelt dat appje voor (van dierenartsen horen ze wel dat zij blij zijn met de WhatsApp mogelijkheid). Doorlezen van de verslagen zou inspecteurs veel tijd kosten: 'heel veel papiertjes, niet door te komen'. De inspecteurs concluderen dat de bepalingen rondom het contactmoment eigenlijk niet handhaafbaar zijn.

Tot slot; de inspecteurs geven aan dat de wijzigingen ten aanzien van contactmoment niet hebben geleid tot een betere praktische werkbaarheid van de handhaving op deze bepalingen.

\subsubsection{Vrijstelling voor bedrijven met een structureel laag antibioticumgebruik}

Bedrijven met een structureel laaggebruik kunnen vrijstelling krijgen van een aantal UDD-bepalingen. Probleem voor de NVWA is dat ze zelf niet kan inzien of een veehouder vrijstelling heeft gekregen. Dit omdat inspecteurs niet beschikken over alle antibioticumgebruiksgegevens van een veebedrijf in de tijd en ook geen toegang hebben tot de gegevens waarmee inspecteurs dit zelf op een correcte manier zouden kunnen berekenen (los daarvan zou dat ook te tijdrovend zijn). Dit maakt het lastig om risicogericht controles uit te voeren, die juist bij laaggebruikers als zinvol worden ervaren. Dat bedrijven vrijstelling hebben komt pas aan het licht bij de steekproefsgewijze controles (of in een enkel geval na melding van bv. het slachthuis indien bepaalde waarden boven de MRL zitten). De inspecteur vraagt dan aan de veehouder zelf of deze gebruik maakt van de vrijstelling voor laaggebruikers. Of voldaan wordt aan de criteria voor de vrijstelling wordt niet gecontroleerd.

\subsubsection{Slotopmerkingen NVWA-inspecteurs}

\section{Met betrekking tot de herziening}

Qua praktische uitvoerbaarheid/werkbaarheid van de handhaving is er met de wijzigingen op de UDDregeling per 1-1-2017 weinig veranderd: de controle op de UDD-regeling was en blijft lastig. De aanwezigheid van open normen binnen de (wijzigingen op) de UDD-regeling en de controle daarop wordt als lastig ervaren. Alleen concrete normen zijn goed handhaafbaar.

Algemene aandachtspunten

De NVWA kan niet beschikken over alle antibioticumgebruikscijfers van alle bedrijven. Daardoor wordt risicogericht controleren op naleving van de (wijzigingen op) de UDD-regeling als lastig ervaren. 


\section{$4 \quad$ Conclusies en aanbevelingen}

Overall doel van de evaluatie was om na te gaan of de herziening van de UDD-regeling de praktische werkbaarheid heeft vergroot. In de evaluatie stond de volgende onderzoeksvraag centraal:

Heeft de herziening van de UDD-regeling geleid tot een betere praktische werkbaarheid van deze regeling in de sectoren melkvee, varkens en vleeskalveren, met betrekking tot:

- het inzetten van tweede keuze middelen, specifiek op het gebied van:

- bedrijfsspecifieke aandoeningen;

- maximalisatie van de voorraad tweede keuze middelen;

- contactmomenten voorafgaand aan inzet van tweede keuze middelen;

- en vrijstellingen voor bedrijven met een structureel laag antibioticagebruik.

De evaluatie betrof uitsluitend de wijzigingen van de UDD-regeling, ingegaan op 1-1-2017, en niet de gehele UDD-regeling.

NB. Het bleek tijdens de interviews dat het, ondanks de voorbereide vragenlijst die met name was toegespitst op de herziening van de regeling, bijzonder lastig was om discussies over de herziening van de regeling apart te voeren van en niet te laten verstrengelen met discussies over de gehele UDDregeling en andere aspecten van het veterinair handelen. In de samenvatting van de interviews met sectordierenartsen en NVWA-inspecteurs (hoofdstuk 3) zijn beide type ervaringen dan ook niet altijd strikt te scheiden van elkaar.

In dit hoofdstuk is dit onderscheid wel zo goed mogelijk gemaakt. In 4.1 zijn onze conclusies en aanbevelingen ten aanzien van de praktische werkbaarheid van de herziening samengevat. In 4.2 zijn meer algemene aandachtspunten in relatie met werkbaarheid van de UDD-regeling en andere aspecten van het veterinair handelen rondom antibiotica, zoals naar voren gekomen uit de interviews, samengevat.

\subsection{Conclusies en aanbevelingen m.b.t. de herziening}

$>$ Bedrijfsspecifieke aandoeningen Het werken met een top-3 van bedrijfsspecifieke aandoeningen in plaats van met sectorale knelpuntaandoeningen wordt in het algemeen als een verbetering ten opzichte van de oude UDD-regeling gezien.

Voor de vleeskalversector maakt deze herziening niet veel verschil, aangezien het doorgaans om dezelfde drie aandoeningen als de eerdere knelpuntaandoeningen gaat (artritis, enteritis en luchtwegproblemen).

Voor de varkenssector is het mogen werken met bedrijfsspecifieke aandoeningen een belangrijke verbetering, en de garantie dat er tweede keuze middelen op het bedrijf aanwezig mogen zijn. Incidenteel zijn meer dan drie bedrijfsspecifieke aandoeningen gelijktijdig relevant, samenhangend met de aanwezigheid van meerdere diercategorieën op een varkensbedrijf, met elk hun eigen kenmerkende aandoeningen. De restrictie tot drie aandoeningen wordt dan soms als te beperkt ervaren.

Binnen de melkveesector werken de dierenartsen bij voorkeur niet met bedrijfsspecifieke aandoeningen, hooguit bij enkele melkveebedrijven op m.n. grotere afstand. Ze nemen bedrijfsspecifieke aandoeningen doorgaans niet op in het BBP en BGP. Belangrijkste reden is de angst voor 'administratieve fouten' en de persoonlijke consequenties die dat kan hebben. Net als bij vleeskalveren gelden ook op melkveebedrijven veelal nog steeds dezelfde structurele aandoeningen als de knelpuntaandoeningen in de eerdere regeling; voor melkveebedrijven is dat neonatale kalverdiarree. 
> Administreren van bedrijfsspecifieke aandoeningen in BBP Volgens de wet dient het BBP éénmaal per jaar te worden vastgesteld, of tussentijds te worden aangepast indien er een bedrijfsspecifieke aandoening bijkomt of verandert (tot max. 3). Dierenartsen uit de verschillende sectoren zijn voorstander van een variant waarbij ook de visitebrief lopende het jaar als addendum op BBP (en BGP) mag functioneren, in het geval dat er sprake is van een nieuwe aandoening met een structureel karakter (eveneens tot max. 3). Een variant met de visitebrieven als addendum heeft als voordeel een meer dynamische werkwijze, die veel beter aansluit bij de praktische werkbaarheid voor dierenarts en veehouder. Het BBP zelf hoeft in dat geval dan slechts éénmaal per jaar, tijdens de jaarlijkse evaluatie van BGP en BBP met de veehouder, te worden aangepast.

> Onderbouwing van bedrijfsspecifieke aandoeningen in BGP De herziening van de UDD-regeling heeft op het punt van onderbouwing van de aandoeningen in het BGP, waarvoor de veehouder tweede keuze middelen op voorraad mag hebben, geen verandering gebracht ten opzichte van de eerdere knelpuntaandoeningen. De bevraagde inspecteurs geven aan dat in de UDD-regeling niet is gespecificeerd aan welke eisen de omschrijving van bedrijfsspecifieke aandoeningen in het bedrijfsgezondheidsplan moet voldoen. Handhaving op een dergelijke open norm is lastig, in de regelgeving is niet concreet genoeg omschreven waarop men moet handhaven. Niet alleen voor de toezichthouder is dit een probleem, ook voor dierenartsen en hun veehouders levert dit veel onzekerheid op: het is niet duidelijk wanneer is voldaan aan de regels en hoe toezichthouders (publiek/privaat) hier mee om (moeten) gaan. In de regeling is evenmin gespecificeerd aan welke eisen de beschrijving van verbetermaatregelen in het BGP moeten voldoen. De beschrijving van een verbeterplan blijft doorgaans vrij algemeen, soms wordt verwezen naar een algemeen actieplan. Bepaalde bedrijfsgebonden aandoeningen kunnen een hardnekkig en structureel probleem door de jaren heen vormen. Volgens de dierenartsen onderstreept dit dat er op korte termijn geen 'eenvoudige' oplossingen zijn. ${ }^{1} \mathrm{Bij}$ renovatie en nieuwbouw zijn er soms wel belangrijke verbeteringen mogelijk.

> Maximalisatie voorraad tweede keuze middelen

Voor vleeskalveren betrof dit geen herziening van de regeling (was al in de eerdere regeling opgenomen).

De dierenartsen voor melkvee ervaren geen specifieke voor- of nadelen in de praktische werkbaarheid door deze herziening. Het op voorraad houden van tweede keuze middelen komt in de melkveepraktijk weinig voor. De voorraadmaximalisatie van $10 \%$ van de aanwezige en voor kalverdiarree vatbare kalveren vindt men relevant (die van $10 \%$ voor melkkoeien aan de hoge kant).

Varkensdierenartsen ervaren het als een grote uitdaging om te berekenen of men niet over de maximaal toegestane voorraad per afdeling heengaat. Een duidelijk nadeel van de herziening vindt men de term 'afdeling' waarvoor de maximalisatie van de voorraad geldt, omdat op bedrijven met zeugen de geboorte van biggen een continu proces is en vaak wekelijks de afdelingsnummers wijzigen. Een voorraadmaximalisatie per leeftijdscategorie (zuigende biggen, gespeende biggen e.d.) in plaats van per afdeling zou de praktische werkbaarheid (sterk) vergroten.

> Contactmoment In de vleeskalverhouderij wordt nauwelijks gebruik gemaakt van het contactmoment. Er wordt, evenals voor de herziening, vrijwel altijd een bedrijfsbezoek afgelegd vóór inzet van een tweede keuze middel. Belangrijke reden is om een beter beeld te hebben van wat er speelt, maar bovenal omdat de regelgeving rond het verplichte contactmoment door de dierenartsen als te ingewikkeld en complex wordt ervaren. In de varkenssector wordt eveneens nauwelijks gebruik gemaakt van het contactmoment, men beoordeelt de praktische werkbaarheid ervan als zeer negatief (er zouden teveel

\footnotetext{
${ }^{1}$ Als meer lange-termijn oplossingen voor structurele gezondheidsproblemen noemden veterinairen in de tussentijdse evaluatie van de UUD-regeling (Kluivers et al., 2015) kennisontwikkeling en -uitwisseling over effectieve preventiemaatregelen, versterkte samenwerking tussen erfbetreders, versterking van dier- en voerkwaliteit, en meer transparantie en samenwerking in de keten.
} 
contactmomenten nodig zijn tussen varkenshouder en dierenarts). Waar nodig worden bedrijven tweewekelijks bezocht.

In de melkveesector wordt nauwelijks gebruik gemaakt van de regeling rondom het op voorraad houden van tweede keuze middelen, en is de regeling rondom het contactmoment daarmee ook nauwelijks relevant. In algemene zin verlopen contactmomenten met melkveehouders niet veel anders dan voor de herziening, namelijk via telefoon of WhatsApp. Instructies worden in alle sectoren doorgaans per visitebrief vastgelegd. Daarin wordt vaak geen specifieke geldigheidstermijn van de instructie genoemd. De frequentie van de bedrijfsbezoeken functioneert veelal als geldigheidstermijn.

De inspecteurs geven aan dat de herziening van de regeling ten aanzien van de bepalingen rondom het contactmoment niet heeft geleid tot een betere praktische werkbaarheid van de handhaving.

$>\quad$ Vrijstellingsregeling bij laag gebruik Binnen de vleeskalversector wordt weinig gebruik gemaakt van de vrijstellingsregeling voor laaggebruikers. Vrijstelling van de verplichte tweewekelijkse bedrijfsbezoeken tijdens de hoog-risico-periode is voor kalverbedrijven geen stimulans: juist in deze periode is frequente veterinaire zorg het meest relevant en standaard. Voor de varkenssector wordt de vrijstellingsregeling als zeer prettig ervaren, de praktische werkbaarheid is erdoor vergroot en het vormt een terechte waardering voor 'lage' bedrijven. De praktische werkbaarheid kan verder worden vergroot door via vaste ijkmomenten en/of via de IKB-systemen op ieder moment duidelijk te hebben welke bedrijven ervoor in aanmerking komen. Het is de dierenartsen niet duidelijk of de vrijstellingsregeling geldt per bedrijf of ook per leeftijdscategorie mag worden toegepast. Bijvoorbeeld, indien alleen de categorie vleesvarkens in het rode gebied zit, mag de vrijstelling dan wel worden toegepast op de categorieën met de zeugen en de biggen. Er is behoefte aan duidelijkheid hierover. Binnen de melkveesector wordt wisselend gebruik gemaakt van de vrijstellingsregeling: volgens sommige dierenartsen niet of nauwelijks, volgens andere volop. Voor meerdere dierenartsen zouden een DDDA per diercategorie, apart voor zowel melkkoeien als kalveren, en een daaraan gekoppelde vrijstellingsregeling meer zeggen dan per bedrijf, omdat de variatie in antibioticumgebruik tussen bedrijven juist bij de categorie kalveren vrij groot is. Binnen de vrijstellingsregeling mag worden volstaan met één bedrijfsbezoek per jaar aan het melkveebedrijf. Dit vinden de dierenartsen niet gewenst: de frequentie is dan onvoldoende om veterinair een vinger aan de pols te houden.

\section{Algemene conclusies met betrekking tot de herziening}

Zowel de vleeskalver- als varkensdierenartsen geven aan dat de herziening van de UDD-regeling in 2017 enige ontspanning c.q. versoepeling heeft gebracht. Volgens de kalverdierenartsen heeft het de praktische werkbaarheid niet veranderd, het sluit wel beter aan bij wat de sector al deed. De varkensdierenartsen geven aan dat er met de bedrijfsspecifieke aandoeningen ten opzichte van de knelpuntaandoeningen en met de vrijstellingsregeling zeker verbetering is opgetreden, en dat de uitvoering nu beter is te doen. Volgens de dierenartsen voor melkvee is de praktische werkbaarheid niet veranderd, alleen is op sommige punten de logistiek enigszins vereenvoudigd.

Dit laat onverlet dat er voor alle drie de sectoren nog een aantal uitermate belangrijke aandachtspunten qua praktische werkbaarheid resteren, en dat betreft met name de onzekerheid rondom de open normen. Dat wil zeggen, de wijze waarop bedrijfsspecifieke aandoeningen moeten worden opgenomen in het BBP en beschreven in het BGP (inclusief verbeterplan), en de min of meer onvoorspelbare wijze waarop toezichthouders (publiek/privaat) hiermee omgaan. Dit wordt ook door de bevraagde toezichthouders als uitermate lastig controleerbaar ervaren. Omwille van vergroting van de praktische werkbaarheid wordt tevens bepleit om de visitebrieven lopende het jaar als formeel addendum op BBP en BGP te accepteren. 


\subsection{Algemene aandachtspunten}

Hierna zijn een aantal algemene aandachtspunten weergegeven, die naar voren kwamen uit de interviews.

> Tegenstrijdigheid in verantwoordelijkheden De wetgever geeft veehouders de mogelijkheid om tweede keuze middelen bij individuele dieren in te zetten. De omvang van individuele behandeling met tweede keuze middelen is (heel) beperkt ten opzichte van het totale antibioticumgebruik binnen de sectoren. De aan deze individuele inzet gekoppelde regelgeving daarentegen is in de beleving van dierenartsen (onevenredig) uitgebreid en complex, waarbij bovendien juist de dierenarts in belangrijke mate dient te verifiëren dat de veehouder in deze professioneel handelt. Scholing/certificering van veehouders is een mogelijkheid om competenties van veehouders/dierverzorgers in het gebruik van (tweede keuze) antibiotica aantoonbaar te maken, en onder deze voorwaarden toe te staan. De verantwoordelijkheid voor het professioneel handelen ligt dan bij de veehouder. Het is daarbij zinvol om na te gaan op welke wijze de administratieve lastendruk rondom de individuele inzet van tweede keuze middelen (dan) binnen de regelgeving kan worden verminderd (mede in proportionaliteit tot de omvang van het gebruik).

> Definitie individuele versus koppelbehandeling Het verschil in definitie tussen individuele en koppelbehandeling is voor de praktijk niet altijd duidelijk, met name waar het de afbakening naar aantal dieren betreft. De vraag is wanneer medicatie door het water of over het voer, die op maat wordt verstrekt aan enkele dieren tot een kleine groep (bijvoorbeeld op kraamhokniveau), onder de definitie van individuele behandeling of onder de definitie van koppelbehandeling valt. Er is behoefte aan duidelijkheid hierover.

> Formularium diergeneesmiddelen en bijsluiters Bepaalde veterinair belangrijke antibiotica zijn in Nederlandse formularia als tweede keuze middel geclassificeerd, terwijl het in omringende landen eerste keuze middelen zijn. Harmonisatie hierin vinden dierenartsen belangrijk. Daarnaast is het van belang dat bijsluiters up-to-date zijn. Aanpassingen in deze kunnen het draagvlak voor de gehele UDD-regeling onder dierenartsen en veehouders versterken.

> Risico-gebaseerde controles op naleving De toezichthouder geeft aan niet te kunnen beschikken over alle antibioticumgebruikscijfers van alle bedrijven; daardoor wordt risicogericht controleren op naleving van de (wijzigingen op) de UDD-regeling als lastig ervaren. 


\section{Literatuur}

Kluivers, Marion, Gisabeth Binnendijk, Maudia Wijhe, Francesca Neijenhuis en Martien Bokma, 2015. Tussenevaluatie knelpuntaandoeningen en praktische uitvoerbaarheid UDD-regeling. Wageningen Livestock Research, Rapport nr. 904.

Kamerbrief betreffende 'Dierziektebeleid' van 2 december 2016 (Kenmerk DGAN-DAD 29683-221). 


\section{Bijlage 1 Vragenlijst interviews}

De overkoepelende vragenlijst is hieronder weergegeven. Voor de betreffende sectoren en voor de NVWA is de vragenlijst specifiek gemaakt en zijn alleen de relevante vragen opgenomen. De overall vraag voor de sectoren was of de herziening van de UDD-regeling heeft geleid tot een betere praktische werkbaarheid van de regeling. Voor de NVWA is het toegespitst op een betere praktische werkbaarheid van de handhaving van de regeling, en is doorgevraagd over wat men in de praktijk aan veranderingen ziet ten aanzien van de praktische werkbaarheid.

\begin{tabular}{|c|c|c|c|}
\hline $\begin{array}{l}\text { Onderdeel UDD- } \\
\text { regeling }\end{array}$ & Oud (1-3-2014) & Nieuw (1-1-2017) & $\begin{array}{l}\text { Wijziging } \\
\text { betreft } \\
\text { diersoort/sector }\end{array}$ \\
\hline $\begin{array}{l}\text { Bedrijfsspecifieke } \\
\text { aandoeningen, } \\
\text { voorraad } 2^{\mathrm{e}} \text { keuze } \\
\text { middelen }\end{array}$ & $\begin{array}{l}\text { Knelpuntaandoeningen } \\
\text { (sectorspecifiek) }\end{array}$ & $\begin{array}{l}\text { Bedrijfsspecifieke } \\
\text { aandoeningen, voorwaarden: } \\
\text { - } \quad \text { Max } 3 \text { stuks } \\
\text { - } \quad \text { Vaak problemen gevend } \\
\text { - } \quad \text { Acuut handelen } \\
\text { noodzakelijk } \\
\text { - Vermeld in } \\
\text { bedrijfsbehandelplan } \\
\text { - Onderbouwing noodzaak } \\
\text { aanwezigheid 2 keuze } \\
\text { middelen en aanvullende } \\
\text { maatregelen in } \\
\text { bedrijfsgezondheidsplan }\end{array}$ & $\begin{array}{l}\text { Melkvee } \\
\text { Vleeskalveren } \\
\text { Varkens }\end{array}$ \\
\hline Vragen & \multicolumn{3}{|c|}{$\begin{array}{l}\text { Melkvee, vleeskalveren, varkens: } \\
\text { - } \quad \text { In de herziene UDD-regeling wordt gewerkt met bedrijfsspecifieke } \\
\text { aandoeningen in plaats van sectorspecifieke knelpuntaandoeningen. Hoe } \\
\text { heeft deze verandering de praktische werkbaarheid beïnvloed? } \\
\text { - Welke voordelen ervaart u ten opzichte van de knelpuntaandoeningen? } \\
\text { - } \quad \text { Welke nadelen ervaart u ten opzichte van de knelpuntaandoeningen? } \\
\text { - } \quad \text { Hoe is de praktische werkbaarheid van de onderbouwing in het } \\
\text { bedrijfsgezondheidsplan van de noodzaak voor aanwezigheid van de } 2^{\mathrm{e}} \\
\text { keuze middelen op het bedrijf? } \\
\text { - Hoe is dit voor de beschrijving van de aanvullende maatregelen die } \\
\text { - } \quad \text { Hetroffen moeten worden om de aandoeningen te voorkomen? } \\
\text { - Heeft u nog andere opmerkingen tav deze wijziging van de UDD- } \\
\text { regeling? }\end{array}$} \\
\hline $\begin{array}{l}\text { Maximalisatie } \\
\text { voorraad }\end{array}$ & $\begin{array}{l}\text { - } 1^{\mathrm{e}} \text { keuze middelen } \\
15 \% \text { aanwezige en } \\
\text { vatbare dieren } \\
\text { - } 2^{\mathrm{e}} \text { keuze middelen } \\
\text { voor mastitis } 15 \% \\
\text { aanwezige en } \\
\text { vatbare dieren op } \\
\text { een bedrijf } \\
\text { (melkvee) } \\
2^{\mathrm{e}} \text { keuze middelen } \\
5 \% \text { aanwezige en } \\
\text { vatbare dieren } \\
\text { (vleeskalveren) in } \\
\text { een stal }\end{array}$ & $\begin{array}{l}\text { Aanvullend: } \\
\begin{array}{l}\text { - } \quad \text { e keuze middelen } 10 \% \\
\text { op het bedrijf aanwezige } \\
\text { en vatbare } \\
\text { melkveerunderen } \\
\text { - } \quad \text { 2e keuze middelen } 10 \%^{\text {in de afdeling aanwezige }} \\
\text { en vatbare varkens }\end{array}\end{array}$ & $\begin{array}{l}\text { Melkvee } \\
\text { Varkens }\end{array}$ \\
\hline
\end{tabular}




\begin{tabular}{|c|c|c|c|}
\hline Vragen & \multicolumn{3}{|c|}{$\begin{array}{l}\text { Melkvee: } \\
\text { - } \quad \text { Naast } 2^{\mathrm{e}} \text { keuze middelen voor mastitis mogen onder de herziene } \\
\text { regeling ook } 2^{\mathrm{e}} \text { keuze middelen voor andere (bedrijfsspecifieke) } \\
\text { aandoeningen op voorraad zijn (max } 10 \% \text { van de op het bedrijf } \\
\text { aanwezige en vatbare runderen). Hoe heeft deze verandering de } \\
\text { praktische werkbaarheid beïnvloed? } \\
\text { - } \quad \text { Welke voordelen heeft dit ten opzichte van de oude regeling? } \\
\text { - } \quad \text { Welke nadelen heeft dit ten opzichte van de oude regeling? } \\
\text { - } \quad \text { Heeft u tips voor collegas m.b.t. de praktische werkbaarheid op dit } \\
\text { punt? } \\
\text { Heeft u nog andere opmerkingen t.a.v. deze wijziging van de UDD- } \\
\text { regeling? } \\
\text { Varkens: } \\
\text { - Naast } 1^{\mathrm{e}} \text { keuze middelen mogen onder de herziene regeling ook } 2^{\mathrm{e}} \\
\text { keuze middelen voor andere (bedrijfsspecifieke) aandoeningen op } \\
\text { voorraad zijn (max } 10 \% \text { in afdeling aanwezige en vatbare varkens). Hoe } \\
\text { heeft deze verandering de praktische werkbaarheid beïnvloed? } \\
\text { Welke voordelen heeft dit ten opzichte van de oude regeling? } \\
\text { - Welke nadelen heeft dit ten opzichte van de oude regeling? } \\
\text { - Heeft u tips voor collega's m.b.t. de praktische werkbaarheid op dit } \\
\text { punt? } \\
\text { Heeft u nog andere opmerkingen t.a.v. deze wijziging van de UDD- } \\
\text { regeling? }\end{array}$} \\
\hline $\begin{array}{l}\text { Contactmoment } \\
\text { voorafgaand aan } \\
\text { inzet } 2^{\mathrm{e}} \text { keuze } \\
\text { middelen bij } \\
\text { individuele dieren }\end{array}$ & $\begin{array}{l}\text { - } \text { Dierenarts heeft in } \\
\text { een periode van } \\
14 \text { dagen } \\
\text { voorafgaand aan } \\
\text { de toepassing van } \\
\text { het middel het } \\
\text { bedrijf bezocht en } \\
\text { geconstateerd dat } \\
\text { behandeling van } \\
\text { individuele dieren } \\
\text { met een middel } \\
\text { van tweede keuze } \\
\text { noodzakelijk is }\end{array}$ & 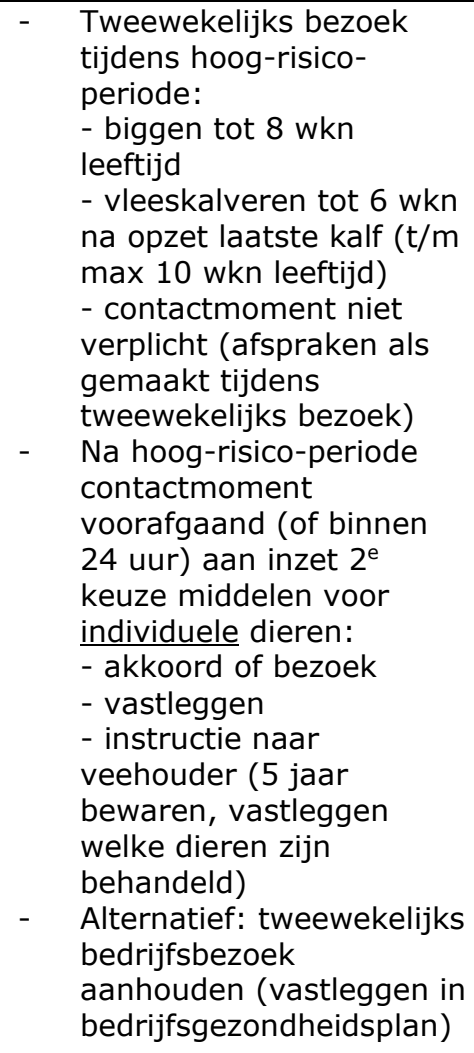 & $\begin{array}{l}\text { Melkvee } \\
\text { Vleeskalveren } \\
\text { Varkens }\end{array}$ \\
\hline
\end{tabular}




\begin{tabular}{|c|c|c|c|}
\hline Vragen & \multicolumn{3}{|c|}{$\begin{array}{l}\text { Melkvee, vleeskalveren, varkens: } \\
\text { - } \quad \text { Hoe ervaart u de praktische werkbaarheid van de aanpassing in de } \\
\text { UDD-regeling voor wat betreft het verplichte bedrijfsbezoek (in de } 14 \\
\text { dgn) voorafgaand aan inzet van } 2^{\text {e }} \text { keuze middelen, nl. omzetting in een } \\
\text { verplicht contactmoment? } \\
\text { - Maakt u in de hoog-risico-periode aanvullend gebruik van het } \\
\text { contactmoment met de veehouder voor inzet van } 2^{\mathrm{e}} \text { keuze middelen of } \\
\text { uitsluitend van de tweewekelijkse bezoeken? } \\
\text { - Welke vorm gebruikt u voor het contactmoment? (telefonisch, } \\
\text { WhatsApp, email, ...) } \\
\text { - Hoe ervaart u de praktische werkbaarheid van het vastleggen van het } \\
\text { contactmoment in uw administratie? } \\
\text { - Hoe ervaart u de praktische werkbaarheid van het voorzien van de } \\
\text { veehouder van de instructie voor inzet van de middelen? } \\
\text { - Welke termijn hanteert u voor de geldigheid van de instructie? } \\
\text { - Heeft u met uw veehouders afspraken gemaakt over vervangen tijdens } \\
\text { afwezigheid/onbereikbaarheid van de } 1 \text {-op-1 dierenarts? } \\
\text { Bij inzet van een koppelkuur moet altijd een bezoek afgelegd worden. } \\
\text { Hoe ervaart u de praktische werkbaarheid hiervan? (niet bij melkvee) } \\
\text { Varkens (aanvullend): } \\
\text { - Hoe ervaart u de praktische werkbaarheid van het tweewekelijkse } \\
\text { bedrijfsbezoek tijdens de hoog-risico-periode op gesloten bedrijven? } \\
\text { (altijd biggen jonger dan } 8 \text { weken aanwezig) }\end{array}$} \\
\hline $\begin{array}{l}\text { Vrijstelling } \\
\text { bedrijven met } \\
\text { structureel laag } \\
\text { gebruik }\end{array}$ & Geen & $\begin{array}{l}\text { Vrijstelling van: } \\
\text { - } \quad \text { het evalueren van het } \\
\text { antibioticagebruik bij elk } \\
\text { regulier bedrijfsbezoek; } \\
\text { - } \quad \text { het tweewekelijks } \\
\text { bedrijfsbezoek door de } \\
\text { dierenarts in de hoog- } \\
\text { risicoperiode; } \\
\text { - } \quad \text { het jaarlijks aanscherpen } \\
\text { van de reductiedoel- } \\
\text { stelling; } \\
\text { het driemaandelijks (of } \\
\text { zesmaandelijks) regulier } \\
\text { bezoek voor melkvee- } \\
\text { houderijbedrijven door de } \\
\text { dierenarts. Dit wordt } \\
\text { omgezet in een jaarlijks } \\
\text { bezoek door de } \\
\text { dierenarts. }\end{array}$ & $\begin{array}{l}\text { Melkvee } \\
\text { Vleeskalveren } \\
\text { Varkens }\end{array}$ \\
\hline $\begin{array}{l}\text { Gids voor Goede } \\
\text { Praktijk } \\
\text { structureel } \\
\text { laaggebruik }\end{array}$ & $\begin{array}{l}\text { Verkrijgen: } \\
\begin{array}{ll}\text { - } & 3 \text { opeenvolgende } \\
\text { periodes (halfjaar) } & \text { groen } \\
\text { - } & 6 \text { opeenvolgende } \\
\text { kwartalen groen } \\
\text { - } \quad \text { Laatste } 18 \\
\text { maanden } \\
\text { (halfjaarlijkse } \\
\text { momenten) groen }\end{array}\end{array}$ & $\begin{array}{l}\text { Verliezen: } \\
\begin{array}{l}2 \text { of meer periodes } \\
\text { oranje/rood }\end{array} \\
-\quad 4 \text { kwartalen oranje/rood } \\
-\quad \begin{array}{l}2 \text { halfjaarlijkse } \\
\text { meetmomenten } \\
\text { oranje/rood }\end{array}\end{array}$ & $\begin{array}{l}\text { Melkvee } \\
\text { Vleeskalveren }\end{array}$ \\
\hline Vragen & \multicolumn{3}{|c|}{$\begin{array}{l}\text { Melkvee: } \\
\text { - Hoe ervaart u de praktische werkbaarheid van de voorwaarde met } \\
\text { betrekking tot het verkrijgen van de vrijstelling zoals geformuleerd in de } \\
\text { Gids voor Goede Praktijk? } \\
\text { - Hoe ervaart u de praktische werkbaarheid van de voorwaarde met } \\
\text { betrekking tot het verliezen van de vrijstelling zoals geformuleerd in de } \\
\text { Gids voor Goede Praktijk? }\end{array}$} \\
\hline
\end{tabular}




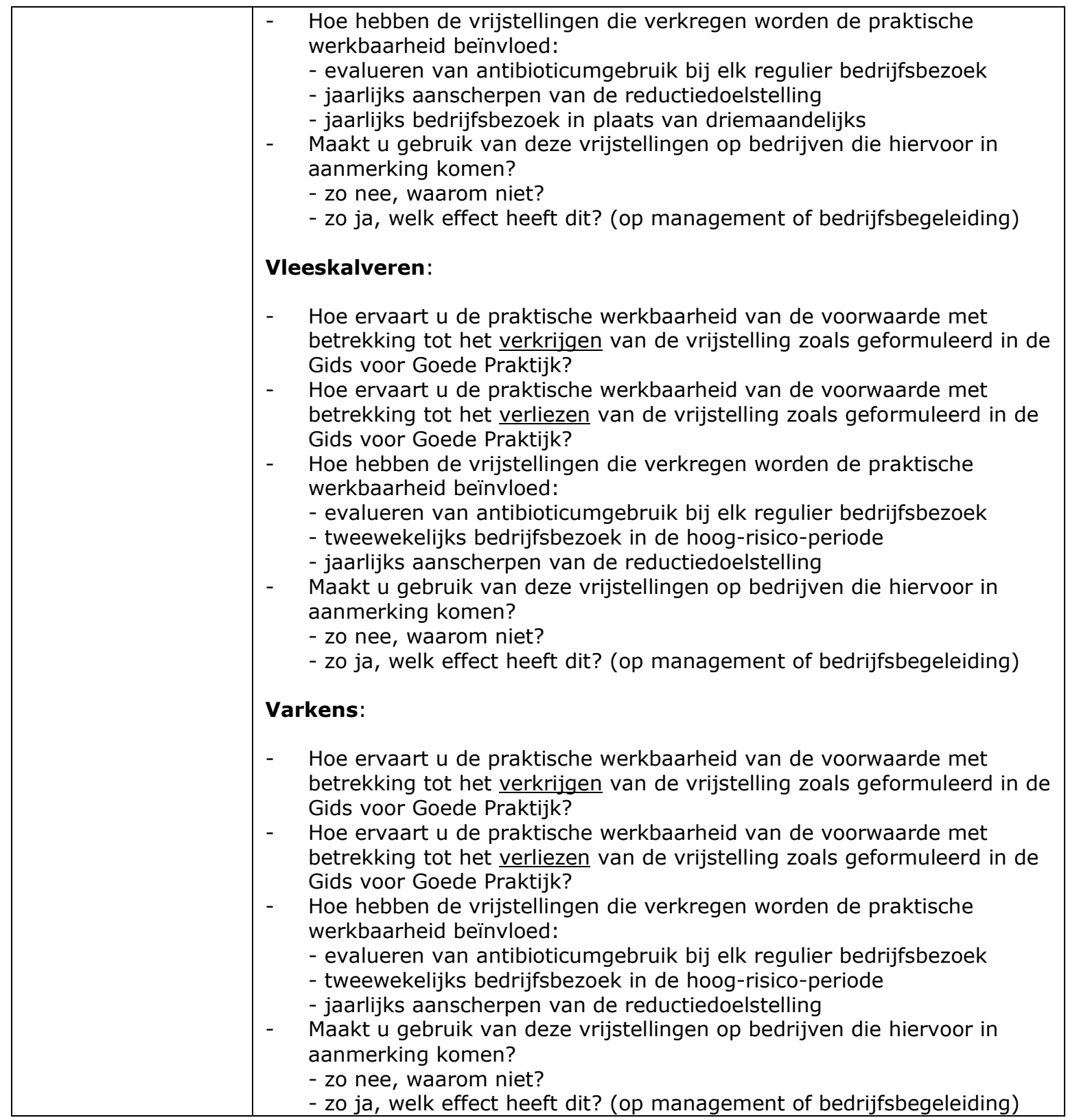

\section{Afsluitende vragen:}

- Heeft de herziening van de UDD-regeling in het algemeen de praktische werkbaarheid veranderd?

- $\quad$ Zijn er nog andere punten ten aanzien van de herziening die u wilt aangeven? 


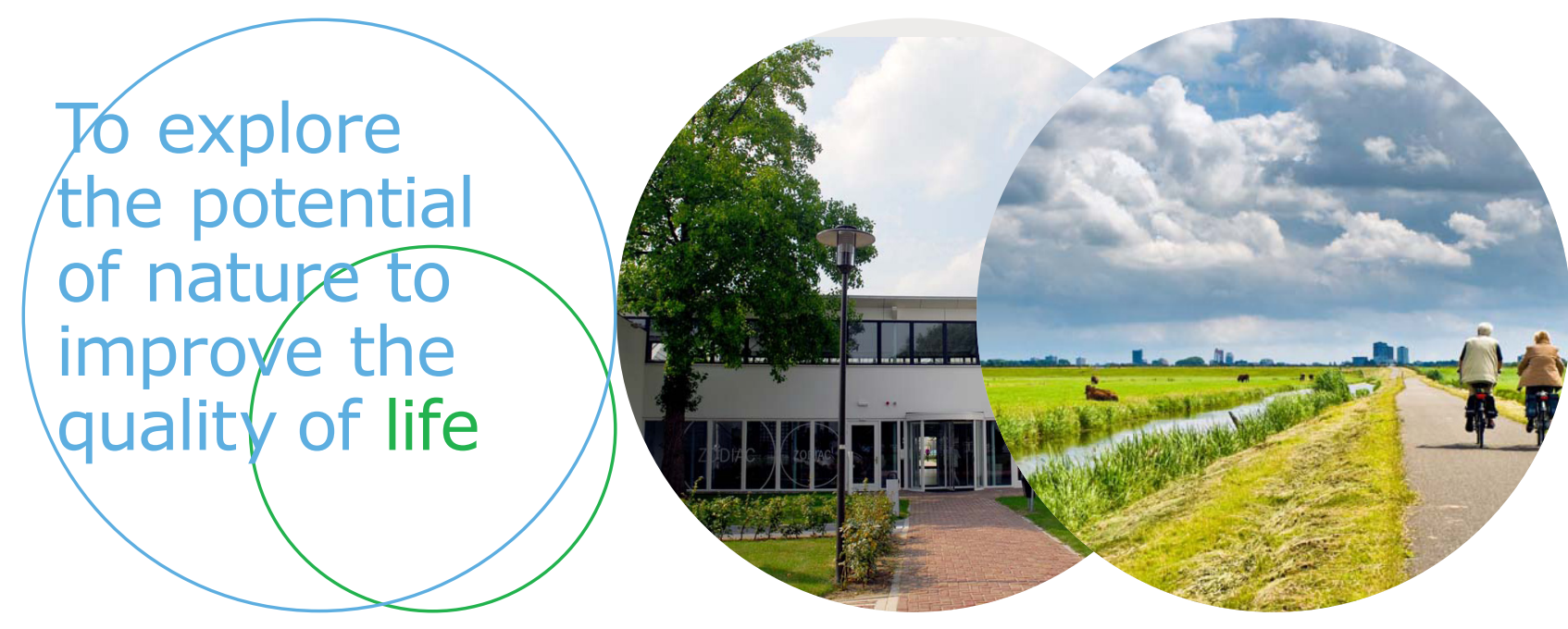

Wageningen Livestock Research Postbus 338

Wageningen Livestock Research ontwikkelt kennis voor een zorgvuldige en $6700 \mathrm{AH}$ Wageningen

T 0317483953

renderende veehouderij, vertaalt deze naar praktijkgerichte oplossingen en innovaties, en zorgt voor doorstroming van deze kennis. Onze wetenschappelijke E info.livestockresearch@wur.nl www.wur.nl/ livestock-research kennis op het gebied van veehouderijsystemen en van voeding, genetica, welzijn en milieu-impact van landbouwhuisdieren integreren we, samen met onze klanten, tot veehouderijconcepten voor de 21 e eeuw.

De missie van Wageningen University \& Research is 'To explore the potential of nature to improve the quality of life'. Binnen Wageningen University \& Research bundelen 9 gespecialiseerde onderzoeksinstituten van Stichting Wageningen Research en Wageningen University hun krachten om bij te dragen aan de oplossing van belangrijke vragen in het domein van gezonde voeding en leefomgeving. Met ongeveer 30 vestigingen, 6.500 medewerkers en 10.000 studenten behoort Wageningen University \& Research wereldwijd tot de aansprekende kennisinstellingen binnen haar domein. De integrale benadering van de vraagstukken en de samenwerking tussen verschillende disciplines vormen het hart van de unieke Wageningen aanpak. 